\title{
El ocaso del dominio español en Costa Firme y su vínculo político y económico con las posesiones aliadas en el Caribe, 1819-1823
}

\author{
The decline of Spanish rule in Costa Firme and its political and \\ economic link with the allied possessions in the Caribbean, 1819-1823
}
O declínio do domínio espanhol na Costa Firme e seu vínculo político e econômico com as possessões aliadas no Caribe, 1819-1823

\author{
Roger Pita Pico ${ }^{1}$ (D) \\ Pontificia Universidad Javeriana, Colombia
}

Para citaciones: Pita, R. (2021). El ocaso del dominio español en Costa Firme y su vínculo político y económico con las posesiones aliadas en el Caribe, 1819-1823. El Taller de la Historia, 13(1), 59-93.

Recibido: enero 2021

Aprobado: abril 2021

Editor: Sergio Paolo Solano. Universidad de Cartagena-Colombia.

Copyright: $\odot$ 2021. Pita, R. Este es un artículo de acceso abierto, distribuido bajo los términos de la licencia https://creativecommons.org/licenses/by-ncsa/4.0/ la cual permite el uso sin restricciones, distribución y reproducción en cualquier medio, siempre y cuando que el original, el autor y la fuente sean acreditados.

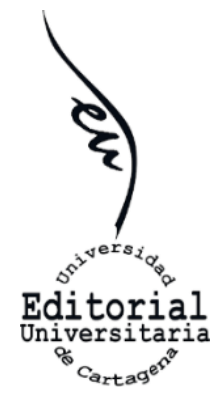

\section{RESUMEN}

En el marco de la conmemoración del bicentenario de la Independencia de las naciones hispanoamericanas, el propósito de este artículo consiste en analizar el declive del antiguo régimen español en los dominios de Costa Firme y la complicada relación con las posesiones insulares aliadas en el Caribe en el intento por lograr respaldo político y ayuda económica en la fase final de la guerra y por ofrecer oportuna atención al ejército realista que de manera progresiva fue debilitándose tanto militar como anímicamente. Finalmente, desde España no se pudo brindar ayuda para evitar que aquellos últimos bastiones del régimen monárquico en Venezuela y Nueva Granada sucumbieran frente al avance de las armas republicanas, ni tampoco le fue posible auxiliar a la desbordada oleada de vecinos, funcionarios y militares emigrados que buscaron refugio inmediato en República Dominicana, Puerto Rico y Cuba. Prácticamente la metrópoli dejó esta alta responsabilidad de ayuda a los gobernantes de estas islas caribeñas en medio de un ambiente político signado por la amenaza y la tensión interna. En aras de la solidaridad que los identificaba como parte de un mismo imperio, las autoridades políticas y militares de estos dominios hispánicos insulares hicieron todo lo que estuvo a su alcance para afrontar esta situación y, ante la falta de recursos oficiales, recurrieron al apoyo solidario de hacendados, comerciantes y vecinos.

Palabras clave: guerras; Independencia; Costa Firme; Caribe; España; emigrados; siglo XIX.

\begin{abstract}
In the framework of the commemoration of the bicentennial of the Independence of the Spanish-American nations, the purpose of this article is to analyze the decline of the old Spanish regime in the dominions of Costa Firme and the complicated relationship with the allied island possessions in the Caribbean in the attempt to obtain political support and economic aid in the final phase of the

\footnotetext{
1 Magíster en Estudios Políticos, Pontificia Universidad Javeriana. Academia Colombiana de Historia. rogpitc@hotmail.com
} 
war and to offer timely attention to the Spanish army, which progressively weakened both militarily and emotionally. Finally, Spain could not provide help to prevent those last bastions of the monarchical regime in Venezuela and New Granada from succumbing to the advance of republican arms, nor was it possible to help the overwhelming wave of emigrated neighbors, officials and military that they sought refuge in the Dominican Republic, Puerto Rico and Cuba. Practically, the metropolis left this high responsibility for aid to the rulers of these Caribbean islands in the midst of a political environment marked by threat and internal tension. For the sake of solidarity that identified them as part of the same empire, the political and military authorities of these insular Hispanic domains did everything in their power to face this situation and, given the lack of official resources, they resorted to solidarity support of landowners, merchants and neighbors.

Keywords: wars; Independence; Costa Firme; Caribbean; Spain; emigrants;19th century.

\section{RESUMEM}

No quadro da comemoração do bicentenário da Independência das nações hispano-americanas, o objetivo deste artigo é analisar o declínio do antigo regime espanhol nos domínios da Costa Firme e a complicada relação com as possessões das ilhas aliadas na o Caribe na tentativa de obter apoio político e ajuda econômica na fase final da guerra e de oferecer atenção oportuna ao exército espanhol, que se debilitou tanto militar como emocionalmente. Finalmente, a Espanha não foi capaz de fornecer ajuda para evitar que os últimos bastiões do regime monárquico na Venezuela e Nova Granada sucumbissem ao avanço das armas republicanas, nem foi possível ajudar a onda esmagadora de vizinhos, funcionários e militares emigrados que eles buscou refúgio imediato na República Dominicana, Porto Rico e Cuba. Praticamente, a metrópole deixou essa grande responsabilidade pela ajuda aos governantes dessas ilhas caribenhas em meio a um ambiente político marcado por ameaças e tensões internas. Por uma questão de solidariedade que os identificou como pertencentes ao mesmo império, as autoridades políticas e militares destes domínios insulares hispânicos fizeram tudo ao seu alcance para fazer face a esta situação e, dada a falta de recursos oficiais, recorreram ao apoio solidário de proprietários de terras, comerciantes e vizinhos.

Palavras-chave: guerras; Independência; Costa Firme; Caribe; Espanha; emigrantes; século XIX

\section{Introducción}

Desde el proceso mismo de conquista y colonización, fueron evidentes los vínculos entre los dominios hispánicos en el Nuevo Mundo. Particularmente entre la Costa Firme ${ }^{2}$ y las islas de Cuba, Puerto Rico y República

${ }^{2}$ Costa Firme comprendía el territorio de la capitanía de Venezuela y el Virreinato de la Nueva Granada. 
Dominicana se observó el flujo de habitantes, funcionarios y mercancías ${ }^{3}$ aunque no siempre de manera constante.

Durante la etapa revolucionaria vivida en Costa Firme a comienzos del siglo XIX, las islas españolas en el Caribe se convirtieron en aliadas naturales frente a la amenaza de los movimientos independentistas. Principalmente, esos territorios insulares brindaron apoyo como plataforma para las expediciones militares dirigidas a zona continental por parte de las autoridades peninsulares, así como también como refugio para los emigrados de la guerra y como respaldo económico a los gobiernos monárquicos que defendían sus territorios en Nueva Granada Venezuela ${ }^{4}$.

Tras los complejos azares de la guerra, esas relaciones entre los dominios españoles continentales e insulares terminaron afectadas y a veces interrumpidas por cuenta de la polarización y el ánimo de retaliación entre los realistas y los republicanos. Una de las primeras consecuencias de ello fue la decisión de las autoridades políticas y militares españolas de desterrar a todos aquellos considerados altamente peligrosos por ser desafectos a la causa monárquica.

Esas expulsiones aumentaron durante la fase de la Reconquista española iniciada en 1815 tras la llegada del ejército expedicionario al mando del teniente general Pablo Morillo. Un ejemplo de ello es el de José Fernández Madrid, el último de los presidentes de las Provincias Unidas durante el primer experimento republicano en la Nueva Granada. En 1816 Morillo lo condenó al exilio en España, pero buscó refugio al hacer escala en Cuba en donde ejerció la medicina y desarrolló una activa vida intelectual ${ }^{5}$. Por otro lado, durante los periodos en que los republicanos estuvieron en el poder, muchos españoles amenazados buscaron por sus propios medios un refugio seguro en otros dominios novohispanos.

La revolución liberal de Riego acaecida al despuntar el año de 1820 y el restablecimiento de la Constitución de Cádiz frustraron el envío de voluminosos recursos y de ejércitos de refuerzo desde España en momentos en que el pie de fuerza en Costa Firme estaba bastante menoscabado por causa de la deserción y de las enfermedades.

En este año las fuerzas realistas que defendían las provincias de Venezuela al mando de Morillo sumaban 12.000 hombres en tanto que las costas neogranadinas eran defendidas por 2.000 hombres. Era un pie de fuerza que superaba las huestes republicanas que contaban en ese momento con 3.000

\footnotetext{
${ }^{3}$ Prueba de ese activo movimiento comercial eran los envíos que se hacían desde Cuba a Cartagena y Puerto Cabello llevando cargamentos de azúcar, miel, tabaco y cobre. Antonino Vidal Ortega, Cartagena de Indias y la región histórica del Caribe, 1560-1640, Sevilla, Universidad de Sevilla, 2002, p. 185.

${ }^{4}$ María Rosario Sevilla Soler, Las Antillas y la Independencia de la América Española (1808-1826), Sevilla, Escuela de Estudios Hispanoamericanos, 1986, p. 13.

5 Ariel Castillo, "José Fernández Madrid: poeta cartagenero de la Independencia", en Haroldo Calvo y Adolfo Meisel (eds.), Cartagena de Indias en la Independencia, Cartagena: Banco de la República, 2011, p. 502.
} 
hombres que al mando del general José Antonio Páez ocupaban los llanos del Apure y además de esto 2.500 hombres que componían el ejército del Norte ubicado en la zona fronteriza con la Nueva Granada ${ }^{6}$.

En el marco de la conmemoración del bicentenario de la Independencia de las naciones hispanoamericanas, el propósito de este artículo consiste en analizar el ocaso del antiguo régimen español en los dominios de Costa Firme y la complicada relación con las posesiones aliadas en Nueva España y el Caribe en el intento por lograr ayuda económica en la fase final de la guerra y por brindar atención a los militares y migrados capitulados.

La realización de esta investigación responde a dos retos historiográficos, específicamente relacionados con el alcance espacial y con la perspectiva del análisis y manejo de las fuentes. Por un lado, se planteó trazar un estudio de carácter regional pues ha primado la tendencia de concentrarse en el proceso de formación de los Estados nacionales, lo cual ha impedido ver de una manera articulada la dinámica vivida en el marco geográfico que comprendía a la Costa Firme y los dominios españoles en el Caribe. En segundo término, la idea es profundizar sobre el proceso de decadencia gradual del imperio hispánico en América desde la perspectiva misma de las autoridades políticas y militares españolas en medio de un contexto en el que ha abundado la producción historiográfica del bando republicano triunfante, vacío este que no ha sido suplido suficientemente ni siquiera por los investigadores peninsulares. Este segundo reto implica, desde luego, auscultar de una manera más detallada las fuentes documentales españolas y para ello se ha tenido como base de consulta el Archivo del general Miguel de la Torre ${ }^{7}$, uno de los fondos más completos emitidos por el alto mando militar realista en América durante el proceso de Independencia.

\section{Visitas, trámites y flujo de militares, funcionarios y migrados}

Desde los inicios del proceso de colonización española en sus dominios americanos, eran inocultables los vínculos entre Venezuela y la Nueva Granada con las islas aliadas de República Dominicana, Puerto Rico y La Habana. Esta situación generó un flujo de funcionarios, militares y vecinos, ya fuera por motivos sociales, económicos, políticos, familiares o afectivos.

Pero lo que antes era un flujo sin mayores contratiempos, pasó a ser mucho más complicado a comienzos del siglo XIX por cuenta de la convulsión política y militar generada por las luchas independentistas. Con la guerra aumentó sustancialmente el tránsito de militares y al viaje por las aguas del mar Caribe se le sumaron una serie de escollos que hacían más inseguro e

\footnotetext{
${ }^{6}$ José Manuel Restrepo, Historia de la Revolución de la República de Colombia en la América Meridional, tomo II, Medellín, Universidad de Antioquia-Universidad Nacional, 2009, p. 10.

${ }^{7}$ Los documentos originales de este archivo reposan en los fondos de la Real Academia de la Historia de España y para esta investigación se consultó una copia mecanografiada agrupada en 35 tomos que se conserva en las colecciones de la Academia Colombiana de Historia.
} 
incierto el trayecto, en especial, los crecientes ataques de corsarios al servicio de cada uno de los bandos contendientes ${ }^{8}$.

El 29 de julio de 1821 el oficial Julián Francisco de Ibarra reportó que su itinerario de Venezuela a Puerto Rico había durado 18 días experimentándose no pocas vicisitudes tras el agotamiento de las reservas de agua. Al arribar a la isla, se supo que los piratas habían apresado cinco buques del convoy, entre ellos la barca Zaragoza y el bergantín Rosalía ${ }^{9}$. El testimonio que aparece descrito a continuación ayuda a ilustrar la situación angustiante padecida a finales de octubre por don Francisco de Gárate, enviado a La Habana en calidad de comisionado del gobierno venezolano español, al ver embarazoso su regreso a Venezuela: “[...] no se presenta ocasión para poder emprender mi viaje, lo que me tiene inquieto. Son muchos los piratas que infestan estas Costas y esto dificulta más mi salida pero pienso aprovechar la primera ocasión de algún buque de guerra para Jamaica u otro punto que me acerque más a ese" 10 .

Durante este periodo de guerra fueron de diversa índole las peticiones que debían tramitarse entre los gobernantes políticos y los altos mandos oficiales de estos dominios hispánicos, con el fin de atender las necesidades y demandas particulares de los militares. El 24 de julio de 1820 el teniente general Pablo Morillo concedió licencia temporal al ayudante de Húsares de Fernando VII don Rafael Morote y al teniente del batallón Ligero de Hostalrich don José Ángel Loira para que pasaran a La Habana a ver sus padres y parientes. El capitán general de la isla don Juan María Echeverri prometió brindar toda la atención necesaria al par de visitantes ${ }^{11}$.

A finales de diciembre de este mismo año el teniente general Juan Manuel de Cajigal, gobernador de La Habana, transmitió al alto mando militar asentado en Caracas la solicitud elevada por doña Sebastiana Correa para que se le emitiera la certificación de defunción de su hijo Manuel Pérez Delgado, teniente de granaderos del $2^{\circ}$ batallón del Regimiento de Infantería de Numancia, quien había sido abatido a manos de los republicanos en el Nuevo Reino de Granada ${ }^{12}$.

El teniente Melchor Hidalgo Yáñez, ayudante $1^{\circ}$ de la plaza de Cumaná, tramitó el 10 de febrero de 1821 ante el gobernador Antonio de Tobar una autorización para pasar a Puerto Rico durante cuatro meses para resolver algunos negocios personales que ameritaban su presencia. Esta impetración la elevó Hidalgo aprovechando la coyuntura de "la ventajosa proporción del

\footnotetext{
${ }^{8}$ Sobre los corsarios véase: Joana Von Grafenstein, "Corso y piratería en el Golfo-Caribe durante las guerras de independencia hispanoamericanas", en Antoine Follain (dir.), Les Justices locales dans les villes et villages du XV $V^{e}$ au XIX siécl,. Rennes:,Presses Universitaires de Rennes, 2006, pp. 269-282.

${ }^{9}$ Academia Colombiana de Historia (ACH), Fondo Archivo del General Miguel de La Torre, tomo XXXV, p. 81.

${ }^{10} \mathrm{ACH}$, Fondo Archivo del General Miguel de La Torre, tomo XVIII, p. 266.

${ }_{11}$ ACH, Fondo Archivo del General Miguel de La Torre, tomo XVII, p. 177.

${ }^{12}$ ACH, Fondo Archivo del General Miguel de La Torre, tomo XVII, p. 178.
} 
armisticio $^{13}$ ". Su propósito era recoger algunos intereses que había dejado pendientes desde cuando regresó de su exilio en esa isla en 1812, recursos con los cuales pretendía mitigar la situación de pobreza que padecía por esos días su crecida familia residente en Cumaná. Tobar consideró que la justa la causa esgrimida por este oficial lo hacía acreedor a tal gracia y remitió la solicitud al general De La Torre para su aprobación final ${ }^{14}$.

A medida que los republicanos lograban estrechar el cerco sobre los españoles en el territorio de Costa Firme, asimismo se multiplicaban las peticiones de las autoridades realistas a los gobernantes de las islas aliadas del Caribe para que acogieran no solo a los militares y funcionarios sino a sus familias y a algunos vecinos emigrados. Desde luego, esto representaba una creciente carga para las arcas oficiales de los gobiernos insulares receptores.

Particularmente, después de la pérdida de la capital Caracas a mediados de 1821, cuando la tensión era mayor y el peligro se hacía más inminente, aumentaron exponencialmente las gestiones de militares, funcionarios y vecinos con miras a agilizar su salida de Costa Firme. Para ello, los peticionarios adujeron varias circunstancias, tales como el estado crítico de salud o en otros casos se tramitaron licencias temporales o definitivas. Desde luego, el alto mando militar en Venezuela no podía dar vía libre a todas las solicitudes, en especial las de los hombres de armas, pues eso podía desencadenar una desbandada en serie que empeoraría el alarmante déficit de pie de fuerza. Cabe precisar que la posibilidad de evacuar el territorio de Costa Firme solo favoreció al cuadro de oficiales pues los grados inferiores que representaban la gran mayoría del Ejército Expedicionario no contaron con esa opción y debieron combatir hasta el último momento o cuando fueron incluidos en procesos de capitulación.

El 23 de mayo de 1821 el general Miguel De La Torre concedió al coronel comandante del batallón Veterano de Maracaibo don Jaime Moreno permiso para trasladarse a Puerto Rico y con él iba doña Manuela Viras, esposa del teniente coronel Feliciano Montenegro, jefe del Estado Mayor del Ejército, junto con la madre de ella y tres de sus hijos. Debido a las críticas circunstancias económicas ocasionadas por la guerra, el clamor de aquel general al capitán general de aquella isla era que asistiera mensualmente a dicha familia con el suministro de cien pesos que era la mitad de la paga de Montenegro $^{15}$.

A causa de los "desgraciados sucesos" acaecidos en Caracas, Manuel Montenegro, administrador de hacienda pública de la Victoria, se había visto precisado a finales de junio de 1821 a emigrar precipitadamente a Puerto Rico abandonando sus intereses. Al ser su intención continuar rindiendo su servicio

\footnotetext{
${ }^{13}$ Tratado de suspensión de hostilidades firmado el 25 de noviembre en Trujillo, Venezuela, entre el general Simón Bolívar en representación del gobierno republicano y el teniente general Pablo Morillo a nombre del gobierno español.

${ }^{14} \mathrm{ACH}$, Fondo Archivo del General Miguel de La Torre, tomo XIII, pp. 223-224.

15 ACH, Fondo Archivo del General Miguel de La Torre, tomo XXVII, p. 6.
} 
al Rey, el general en jefe De La Torre lo recomendó ante el capitán general de la isla para que lo ayudara a ubicar en algún cargo público ${ }^{16}$. Al coronel José Monagas, comandante militar de Valencia, también le fue concedido el pasaporte para salir hacia aquella misma isla debido a estar avanzado en años y a sus numerosos achaques. A principios de agosto, por el cruce epistolar se sabe que este oficial había logrado arribar a su anhelado destino en donde se hallaba asentado al frente del pueblo de Bayamón en una hacienda que compró para sobrevivir económicamente ${ }^{17}$.

Por esos días, el capitán general y gobernador de Puerto Rico, don Gonzalo de Aróstegui, accedió a brindar protección y auxilio a doña María Josefa Méndez de Quero y a sus hijas, otorgándoles parte del sueldo de su esposo por cuenta de la Intendencia de la isla. La misma ayuda se prometió a doña Dominga Flores, viuda del teniente coronel José Guerrero, comandante de las fuerzas sutiles de Cumaná, quien pasó a esa isla tras la ocupación militar de aquella provincia costera venezolana. A ella se le asignaron 60 pesos mensuales de pensión por los "heroicos" servicios de su difunto esposo. También se recomendó suministrar ayuda a las familias de los emigrados doña Josefa del Pumar, don Diego López, don Ramón Arteaga y don Antonio Vega $^{18}$.

Aróstegui envió a las autoridades de Venezuela a finales de septiembre de 1821 una carta que había llegado en el último correo de la península dirigida a doña Carlota Guevara de Mascareña, suponiendo que esta mujer había llegado a esta isla como parte de los emigrados venezolanos tras la pérdida de la ciudad de Caracas pero en realidad ella se había quedado enferma en Puerto Cabello y por ello el capitán general decidió remitir allí la carta ${ }^{19}$.

En medio del ambiente de tensión reinante, algunos cuantos buscaron franquear todos los escollos en aras de estar al lado de los suyos. José Antonio Cao había dejado las armas en 1817 luego de haber estado varios años al servicio del Rey en territorio venezolano y optó luego por emprender viaje a Puerto Rico pero al cabo de cinco años regresó a Puerto Cabello cuando esa ciudad costera estaba sitiada por los republicanos. Él decidió escribir a su suegra y a su concuñado que estaban en la cercana localidad de San Felipe en territorio liberado por los republicanos para que lo ayudasen a salir de la bloqueada plaza y para que a través de algún conocido pudieran persuadir al general republicano José Antonio Páez a fin de que le otorgara pasaporte con miras a residenciarse al lado de sus seres queridos ${ }^{20}$.

Menor fue el flujo de emigrados hacia Santo Domingo debido al ambiente de convulsión interna vivido al interior de aquella isla. El $1^{\circ}$ de diciembre de 1821 se declaró en este espacio insular la independencia siendo depuesto su

\footnotetext{
${ }^{16} \mathrm{ACH}$, Fondo Archivo del General Miguel de La Torre, tomo XXVII, pp. 6-7.

${ }_{17} \mathrm{ACH}$, Fondo Archivo del General Miguel de La Torre, tomo XXVII, p. 366.

${ }^{18} \mathrm{ACH}$, Fondo Archivo del General Miguel de La Torre, tomo XXVII, pp. 39-43.

${ }^{19} \mathrm{ACH}$, Fondo Archivo del General Miguel de La Torre, tomo XXVII, p. 45.

${ }^{20} \mathrm{ACH}$, Fondo Archivo del General Miguel de La Torre, tomo XXXV, pp. 648-653.
} 
capitán general, pero al poco tiempo fue invadida por los haitianos ${ }^{21}$. Ese primer día de diciembre entró al puerto un buque procedente de Curazao con familias de los emigrados de Costa Firme, pero fue imposible que saltaran a tierra a pesar de los reiterados intentos. Con el ánimo de alertar sobre estas incidencias, el cura Bernardo Correa y Cidrón escribió a los pocos días a su amigo don Ramón Hernández quien se hallaba en Venezuela, manifestándole su estado de frustración al no haber podido emigrar a aquella isla. Según relató Correa, el gobierno de la isla se mostró muy generoso al pagar los 600 pesos del flete del buque que debió cambiar de rumbo posiblemente a Puerto Rico o a Santo Tomás. El 5 de diciembre entró otro navío ocupado por emigrados, pero tampoco se le permitió el desembarco ${ }^{22}$.

Entre los dominios continentales y las posesiones insulares que estaban bajo el dominio español continuó durante estos años la circulación de individuos no deseados por sus conductas ilegales a lo cual se le sumaron ahora los desafectos y sospechosos de atentar contra la estabilidad del agónico régimen monárquico. El 30 de marzo de 1821 el capitán general Aróstegui, gobernador de Puerto Rico, embarcó en la goleta correo Clarita con rumbo a las costas de Venezuela a Andrés Luis, Manuel Díaz y Gregorio Andino, hombres que habían sido desterrados a La Habana para purgar sus delitos en la cárcel pero al quedar en libertad incurrieron de nuevo en robos, alborotos y tropelías que alteraban la tranquilidad pública. El pedido que se hacía al general en jefe De La Torre era internarlos en las provincias de Venezuela y no permitirles bajo ninguna circunstancia volver a la isla ${ }^{23}$. El 6 de octubre de ese mismo año, Aróstegui consideró conveniente expulsar al reo puertorriqueño don Pedro Delgado y enviarlo a las costas de Venezuela con el objeto de que, estando lejos de su familia, pudiera “enmendar su carácter". Se pidió a Miguel de La Torre que lo destinara al ejército, servicio que ya había prestado allí hacía algunos años ${ }^{24}$.

En carta enviada el 23 de enero de 1822, La Torre alertó a Aróstegui para que estuviera atento de la conducta sospechosa de algunos de los vecinos y militares que de las provincias de Venezuela habían pasado a aquella isla. Se recomendó estrechar la vigilancia sobre ellos para impedir algún acontecimiento desafortunado, como la insurrección que acababa de ocurrir en Santo Domingo ${ }^{25}$.

Para el año de 1823 eran más que evidentes los avances militares del ejército libertador pues se había logrado la conquista de prácticamente todo el territorio de Venezuela y el gobierno republicano se aseguró de adoptar medidas de seguridad como aquella dictada el 7 de julio por el vicepresidente

\footnotetext{
${ }^{21}$ Mayor era la preocupación al saberse de que era muy corta la fuerza disponible y el estado ruinoso de las fortificaciones. Exposición del estado actual del Ejército Español leída en las Cortes Ordinarias de 1822 el 4 de marzo, conforme al artículo 77 del Reglamento Interior de las Cortes, por el Brigadier don Luis Balanzat, secretario de Estado y del Despacho de la Guerra, Madrid, En la Imprenta Nacional, 1822, p. 29.

${ }^{22} \mathrm{ACH}$, Fondo Archivo del General Miguel de La Torre, tomo XXVII, pp. 168-169.

${ }^{23} \mathrm{ACH}$, Fondo Archivo del General Miguel de La Torre, tomo XXVII, p. 33.

${ }^{24} \mathrm{ACH}$, Fondo Archivo del General Miguel de La Torre, tomo XXVII, p. 46.

${ }^{25} \mathrm{ACH}$, Fondo Archivo del General Miguel de La Torre, tomo XXVII, pp. 14, 60.
} 
Carlos Soublette que ordenaba la expulsión de todos los españoles y canarios que no estuviesen comprometidos con el nuevo sistema político. La mayoría fueron llevados a Cuba y Puerto Rico y otros tantos a las colonias extranjeras insulares.

En estas islas aliadas también se alcanzó a sentir la amenaza de un eventual ataque de las fuerzas independentistas desde Costa Firme, temor que se acrecentó a medida que los republicanos ganaban paulatinamente terreno en su ofensiva, aunque ninguno de esos proyectos llegó a cristalizarse.

En un informe reservado que el general La Torre enviara al alto gobierno en España el 22 de enero de 1821, aseguraba que el general Simón Bolívar, luego de la liberación de Guayaquil, tenía proyectado conquistar Cuba, operación que podía resultarle fácil por la extensión de costas para desembarcar y el eventual apoyo que recibiría de los esclavos seducidos bajo el acicate de la libertad $^{26}$. Un nuevo rumor cundió a principios de julio del año siguiente cuando el comandante de la marina española venezolana don Ángel Laborde puso en alerta a La Torre sobre una supuesta expedición militar republicana que se estaba maquinando en Caracas para liberar a Puerto Rico con el desembarco de 500 a 1.000 hombres bajo el mando del general José Francisco Bermúdez y con la activa participación de corsarios, extranjeros y emigrados disidentes $^{27}$. Días antes, se había conocido en la metrópoli un pronunciamiento de las Cortes en el sentido de no escatimar esfuerzos para blindar de todo riesgo o invasión a Puerto Rico y Cuba ${ }^{28}$. En 1827 hubo un nuevo intento de invasión del general Bolívar dentro de su proyecto de consolidación del proceso independentista en el continente, pero al final todo quedó en meros planes y amenazas ${ }^{29}$.

\section{Ayuda económica desde los dominios aliados en el Caribe}

Desde finales del periodo colonial, Venezuela venía experimentando una disminución en el desarrollo de su economía ${ }^{30}$, todo esto sumado a un incremento sustancial en las imposiciones tributarias. La situación no mostró signos de mejoría con la llegada de las guerras de Independencia y eso se vio reflejado en el estancamiento del comercio marítimo y el mercado doméstico, la caída en los precios de productos claves de exportación como el cacao y el café, la fuga de capitales a las Colonias del Caribe, el abandono de las actividades productivas a causa de la guerra y la escasez de alimentos ${ }^{31}$. El gobierno español veía con suma preocupación cómo sus arcas no mostraban

\footnotetext{
${ }^{26}$ ACH, Fondo Archivo del General Miguel de La Torre, tomo XXVI, p. 48.

${ }^{27} \mathrm{ACH}$, Fondo Archivo del General Miguel de La Torre, tomo XIX, p. 454.

${ }^{28}$ Floralgia Giménez Silva, La Independencia de Venezuela ante las cancillerías europeas, Caracas, Academia Nacional de la Historia, 1961, pp. 360-361.

${ }^{29}$ Un reciente trabajo revisionista sobre las aspiraciones bolivarianas en las islas españolas, véase: Rafat Ahmed Ghotme Ghotme, "La «política antillana» de la Gran Colombia: interpretación realista", Historia y Espacio, 16 (55), (2020): 96-129. ${ }^{30}$ Mercedes Álvarez, Comercio y comerciantes y sus proyecciones en la Independencia venezolana, La Guayra, Tip. Vargas, 1963, pp. 110-112

${ }^{31}$ Antonio Arellano Moreno, Orígenes de la economía venezolana. Caracas: Universidad Central de Venezuela, 1973, pp. 366-373; Rafael Cartay, Historia económica de Venezuela 1830-1900, Valencia, Vadell Hermanos Editores, 1988, pp. 3860 .
} 
signos de recuperación pues buena parte de los recursos se reorientaban hacia los gastos de sostenimiento de la guerra ${ }^{32}$. Todo este panorama resultaba agravado con las órdenes de confiscación, los saqueos, las contribuciones forzosas y demás efectos devastadores de la guerra.

Entre tanto, la costa Caribe neogranadina había mostrado también un deterioro en los índices de su economía pues no hay que olvidar que ese territorio se constituyó en uno de los escenarios más álgidos de la guerra.

Notorios retrocesos se observaron en el comercio que era el principal renglón económico y que se hacía a través de Cartagena, puerto que para 1820 se hallaba sitiado por los republicanos ${ }^{33}$. La falta de una agricultura de exportación ahondó aún más la crisis regional en medio de una incesante demanda de recursos militares y de un decrecimiento demográfico ${ }^{34}$.

A medida que la guerra se prolongaba, asimismo los recursos escaseaban y, por ello, las autoridades realistas de Costa Firme no cesaban de lanzar llamados urgentes de ayuda a España y a los territorios aliados en América pues los gastos de guerra desbordaban el escaso presupuesto en momentos en que urgía también el restablecimiento del crédito público.

A través de una carta fechada el 28 de febrero de 1819, el general en jefe Pablo Morillo acudió ante el ministro de Guerra de España para que interviniera a fin de disminuir las trabas que experimentaban los gobiernos de Cuba y Puerto Rico para auxiliar al ejército expedicionario de Costa Firme en sus urgencias, tal como lo había reportado el capitán general de la primera de aquellas islas, don José Cienfuegos, al intentar enviar auxilios de la marina.

Por su parte, el entonces capitán general de Puerto Rico don Salvador Meléndez se había negado a suministrar las abundantes menestras que allí se producían y que podían ahorrar gastos considerables a la Real Hacienda, además de rehusarse a suministrar otros auxilios. En nada veía Morillo el sentido de la compensación pues al principio de la revolución entraron en las tesorerías de Puerto Rico 130.000 pesos pertenecientes a las cajas reales de Venezuela y hasta el momento no se había logrado el reintegro de estos caudales. Con esta frase, el general en jefe reiteró la importancia de mantener activos esos lazos de cooperación y vaticinó las nefastas consecuencias que sobrevendrían si no se lograba el espíritu de solidaridad como integrantes del imperio español: "Siempre que los países tranquilos no ayuden con sus recursos a los que están en insurrección, se dilatará mucho la pacificación de

\footnotetext{
${ }^{32}$ David Bushnell, El Régimen de Santander en la Gran Colombia. Bogotá: El Áncora, 1985, $3^{\text {a }}$ edición, p. 122.

${ }^{33}$ Adelaida Sourdís, Cartagena de Indias durante la Primera República 1810-1815, Bogotá, Banco de la República, 1988, p. 130 .

34 Alberto Lee López y Horacio Rodríguez Plata (comp.), Documentos sobre la Campaña Libertadora de 1819, tomo III, Bogotá, Editorial Andes, 1971, p. 313. Sobre el impacto de la fase independentista en la economía de la Costa Caribe, véase además: Joaquín Viloria de la Hoz, "La Independencia en la provincia de Santa Marta", Revista del Banco de la República, 88-1.050, (2015): 17-67; Adolfo Meisel, La crisis fiscal de Cartagena en la era de la Independencia, 1808-1821, Cartagena, Banco de la República, 2007.
} 
éstos, y serán muy gravosos al Real erario los medios lentos y tardíos que se empleen" 35 .

Al cabo de cinco meses, habiéndose perdido la capital Santa Fe y la zona central de la Nueva Granada, Morillo volvió a lamentarse por el hecho de que las arcas de Venezuela no alcanzaban a cubrir los inmensos gastos generados por la guerra, en momentos en que las contribuciones extraordinarias y forzosas generaban un creciente descontento en la población. Por ello, aspiraba a que el ministro de Guerra transmitiera al Rey el clamor para que de las cajas de Nueva España y de La Habana se enviasen al menos 60.000 pesos mensuales para apaciguar las privaciones y miserias de la tropa. Aunque semanas atrás habían venido de Cuba algunos vestuarios de mala calidad y barriles de harina, se advirtió que producía mejor efecto y mayor economía en la Tesorería del Ejército el recibo de metálico que las libranzas hechas en las provincias venezolanas por contratas de armamento y víveres que se verificaban a precios excesivos ${ }^{36}$.

Hacia el mes de marzo de 1820 , en momentos en que se había registrado el desembarco de 1.500 legionarios británicos en Riohacha para respaldar la causa republicana en la costa neogranadina, Morillo criticó la indiferencia del capitán de La Habana don Juan Manuel Cajigal quien pudo haber cambiado la suerte de la Nueva Granada si desde los primeros avisos de la ocupación de su capital Santa Fe se hubiese desprendido de 1.000 de sus hombres del total de 3.000 que había traído a la isla. En vano fueron también los ruegos que hizo el expulsado virrey neogranadino Juan Sámano, quien había buscado refugio en Cartagena con una corta guarnición de 500 hombres y cercado por las huestes republicanas que tenían en la mira esa plaza estratégica ${ }^{37}$.

En respuesta a todos estos clamores, por Real Orden del 30 de abril de 1820 y reiterada el 10 de mayo, la Corona dispuso el apoyo de La Habana y Nueva España $^{38}$ a las tropas de Costa Firme, tanto en recursos como en hombres ${ }^{39}$. Sin embargo, esta ayuda no se materializó de manera inmediata y, por ello, para finales de septiembre el teniente general Pablo Morillo debió renovar sus quejas al centro de poder en España ${ }^{40}$.

Hacia el mes de noviembre se logró un respiro en la guerra que venía librándose en territorio de Costa Firme tras la firma de un armisticio de seis meses entre el teniente general Morillo en representación del bando realista y el general Simón Bolívar como máximo representante del gobierno

\footnotetext{
${ }^{35}$ Antonio Rodríguez Villa, El teniente general don Pablo Morillo. Primer Conde de Cartagena, Marqués de la Fuerte (1778-1837), tomo IV, Madrid, Establecimiento Tipográfico de Fortanet, 1910, p. 16.

${ }^{36}$ A. Rodríguez Villa, El teniente general, pp. 77-78.

${ }^{37}$ A. Rodríguez Villa, El teniente general, pp. 115, 167, 173.

${ }^{38}$ Ya existía un antecedente concreto de este tipo de apoyo solidario por cuanto a finales de mayo de 1819 el conde de Venadito, virrey de Nueva España, lamentó no poder responder al llamado hecho por el general en jefe Pablo Morillo para que le enviara 100.000 pesos para aliviar la apurada situación económica vivida en Venezuela. El argumento del virrey era que la economía interna no pasaba por un buen momento aunque prometió colaborar gradualmente en la medida de las posibilidades. ACH, Fondo Archivo del General Miguel de La Torre, tomo XVII, p. 302.

${ }^{39} \mathrm{ACH}$, Fondo Archivo del General Miguel de La Torre, tomo XXII, p. 189.

${ }^{40}$ A. Rodríguez Villa, El teniente general, pp. 177, 232.
} 
republicano. Algunos alivios económicos se estipularon en los numerales $8^{\circ}$ y $10^{\circ}$ de este tratado al quedar abiertas las relaciones comerciales entre los respectivos territorios y se dispuso además que los puertos de Maracaibo y Cartagena quedaban habilitados para el comercio interior tanto para los realistas como para los independentistas a excepción del flujo de armas y pertrechos ${ }^{41}$.

En medio del armisticio, el 18 de febrero de 1821 el general Miguel de La Torre, quien había reemplazado a Morillo como comandante en jefe, escribió al capitán general de la isla de Cuba haciéndole ver el lamentable panorama y el estado de miseria que azotaba al Ejército Expedicionario tras seis años de duras privaciones, cuyas graves consecuencias se habían visto reflejadas en la reciente pérdida de la plaza de Maracaibo. Las raciones eran ínfimas, los hospitales se hallaban desatendidos, las fugas eran incontrolables, las continuas exacciones asfixiaban a los pueblos y la opinión política estaba cada vez más inclinada hacia el bando republicano.

A futuro, no veía La Torre más opción para subsistir que los auxilios en recursos y pie de fuerza que por orden Real debían venir de Nueva España y de Cuba, sin lo cual era prácticamente imposible reabrir las hostilidades. Por ello, pidió que aquellos territorios, ricos en recursos, facilitaran en aras de la solidaridad la mayor cantidad de ayuda posible. Para brindar más detalles de la situación y activar la remisión de los caudales requeridos, la Junta de Conciliación de Caracas envió directamente a La Habana en comisión al coronel Matías de Escuté y a don Francisco Gárate, administrador de alcabalas en Caracas, mientras que a Nueva España fue delegado el teniente coronel don José Olazarra. El propósito era persuadir a aquellos gobiernos sobre el espíritu solidario que debía imperar como partícipes de la nación española: "[...] a fin de que tengan en consideración la suerte de este heroico Ejército cuyos inexplicables sacrificios tienen una influencia directa en la suerte del Nuevo Mundo; y el cual perteneciendo activamente a la Nación española exige de justicia que si no es posible partir con otros sus fatigas, heridas, trabajos y tareas, sí lo es que se partan con él los socorros que otros gozan" 42 .

La Torre puso de presente las penalidades y sacrificios de la tropa y le advirtió al gobernador Cajigal el peligro que podía correr la isla si llegaba a sucumbir Venezuela a manos de los "disidentes" y por ello lo hacía también responsable de ese eventual escenario. Como comprobación de estos fatídicos vaticinios y de la amenaza latente, La Torre le adjuntó un manifiesto interceptado del general Bolívar fechado el 9 de noviembre de 1820 en el que aseguraba que sus ambiciones políticas no se circunscribían a las provincias de Costa Firme sino que se extendían a toda la América hispánica ${ }^{43}$.

\footnotetext{
41 "Tratado de Armisticio", Gaceta de Caracas, 19, Caracas, 6 de diciembre de 1820, f. 95.

${ }^{42} \mathrm{ACH}$, Fondo Archivo del General Miguel de La Torre, tomo XXXIII, p. 17.

${ }^{43}$ ACH, Fondo Archivo del General Miguel de La Torre, tomo XVII, pp. 182-185, 197-198.
} 
A finales de marzo, La Torre reiteró su pedido de ayuda al gobernador de La Habana, específicamente el envío de 500 hombres a Cartagena y 1.5000 a Puerto Cabello, estando aún a la espera de que de Nueva España se remitieran 2.000 más. Confiaba también en los 10.000 pesos que debían consignarse mensualmente desde Nueva España y Cuba en desarrollo de la Real Orden dictada el 14 de noviembre de 1820 por el Ministerio de la Gobernación de Ultramar, habiéndose ya anunciado el 10 de marzo de 1821 la reactivación de hostilidades en Costa Firme tras la ruptura precipitada del armisticio ${ }^{44}$.

Al enterarse de estas gestiones adelantadas por el alto mando realista desde Caracas, el gobernador de Cartagena don Gabriel de Torres veía bastante remota la posibilidad de ayuda, especialmente de La Habana, cuyo gobierno se había mostrado apático frente a las repetidas reclamaciones de ayuda para aliviar la situación de aquella plaza. Torres enfatizaba en la necesidad de contar con 400 o 500 hombres para duplicar el pie de fuerza de su mermada guarnición, respaldo que se hacía más urgente ante el creciente cerco impuesto por los republicanos por vía marítima y terrestre ${ }^{45}$.

Justo por estos días se registraron cambios en la gobernación de La Habana en donde don Nicolás de Mahy había asumido funciones el 3 de marzo. De inmediato, La Torre se aseguró de enterarlo sobre el pedido de tropa, víveres y un buque de guerra, solicitud esta que fue transmitida al comandante general del Apostadero y al Intendente del Ejército ${ }^{46}$. Al cabo de tres semanas, los comisionados Gárate y Escuté fondearon en La Habana y de inmediato adelantaron sus primeros contactos con comerciantes y hacendados de la isla pero con muy pocos resultados. Según reportaron, las arcas oficiales de la isla no alcanzaban a cubrir las necesidades más apremiantes y la coyuntura era realmente difícil debido a la transición en el gobierno y los tumultos que debieron contenerse con ocasión de la revolución de Riego y la publicación de la Constitución española ${ }^{47}$.

Igual de intrincada era la situación política en Nueva España con la proclamación independentista liderada por el general Agustín de Iturbide ${ }^{48}$. El coronel Juan Juez del regimiento de Caballería de Venezuela, residente en ese momento en la isla, veía también con profundo escepticismo las misiones enviadas en busca de ayuda pues los ingresos locales eran pingües mientras que los egresos eran considerables habiendo meses que faltaba dinero para pagar la guarnición, sin que en Nueva España se avizoraran mejores expectativas ${ }^{49}$.

No menos desalentador fue el reporte hecho el 15 de abril por Escuté al tiempo que remitía a La Torre un "cajoncito de tabacos buenos" a manera de

${ }^{44}$ ACH, Fondo Archivo del General Miguel de La Torre, tomo XVII, p. 186.

${ }^{45}$ ACH, Fondo Archivo del General Miguel de La Torre, tomo XXIX, pp. 213-214.

${ }^{46} \mathrm{ACH}$, Fondo Archivo del General Miguel de La Torre, tomo XVII, p. 180.

${ }^{47}$ Julio Le Riverend Brusone, La Habana, espacio y vida, Madrid, Fundación Mapfre, 1992, pp. 197-198.

${ }^{48} \mathrm{ACH}$, Fondo Archivo del General Miguel de La Torre, tomo XXXI, p. 139.

${ }^{49}$ ACH, Fondo Archivo del General Miguel de La Torre, tomo XXXI, p. 136. 
presente. Antes que nada, describió los contrastes que vivía la isla en ese momento con más de 500 buques mayores como fiel constatación de un pujante comercio y del lujo que aún se exhibía en algunos sectores. Sin embargo, se reconocía también que esta actividad se había visto abatida con la recién promulgada ley de aranceles que ahuyentó a varios comerciantes mientras que los fondos públicos yacían exhaustos, además de lo gravoso que le resultaba a la Tesorería de la isla el pago mensual de 10.000 pesos en el abono de sueldos a oficiales de Costa Firme que se hallaban allí en espera de trasladarse a la península. Con palabras corteses, los ministros de la isla expresaron su imposibilidad de suministrar auxilios aunque el intendente Alejandro Ramírez Blanco ofreció despachar 500 quintales de tabaco. Agravaba la situación el descontento popular alimentado con el constante rumor de que este funcionario estaba enriqueciéndose con el envío de aquellos auxilios. Con este desolador panorama en el escenario oficial, las esperanzas estaban cifradas en el Consulado, instancia que tradicionalmente había socorrido al Ejército, para lo cual se nombraron tres comisionados encargados de recaudar entre comerciantes y agricultores lo que tuvieren a bien donar o prestar y, aunque la expectativa era obtener de estos gremios al menos 100.000 pesos, al final fue escasa la concurrencia ante lo cual el Consulado optó por enviar a cada comerciante y agricultor una carta exhortándolos a contribuir a la causa. No obstante, la situación se tornaba más compleja por cuanto el comisionado don Mariano Sixto se encontraba allí también recolectando recursos para la sitiada plaza de Cartagena ${ }^{50}$. Aún por encima de estas dificultades, Escuté aseguró estar haciendo los mayores esfuerzos para el éxito de su gestión, con miras a contar con un reforzado ejército ante la inminente reanudación de la guerra para lo cual insistía en la ley de la justicia y el equilibro pues no se compadecía el cuadro de miseria y privaciones que caracterizaba a la tropa ubicada en Venezuela y las comodidades que aún se percibían en los cuarteles de la guarnición de la isla en donde "[...] cada soldado tiene uno o dos baúles, su famoso catre y su percha para colgar las casacas, morrión, cachucha, etc." ${ }^{.5}$.

Tras varios intentos fallidos, finalmente el Intendente del Ejército anunció el 6 de junio que la corbeta nacional Ceres y el bergantín de guerra Hércules estaban próximos a zarpar con un convoy de víveres y efectos para Puerto Cabello. Respecto al envío de tropas, nada pudo hacer Mahy debido al escaso número de hombres que integraban los cuerpos de la guarnición insular pues apenas alcanzaban a cubrir las atenciones de la plaza y sus dependencias ${ }^{52}$.

Habiendo expirado el armisticio el $1^{\circ}$ de mayo, se reanudaron las operaciones observándose notables avances en la ofensiva republicana con un ejército más fortalecido militar y anímicamente en contraste con la disminución progresiva

\footnotetext{
${ }^{50}$ Con estas sentidas palabras, Escuté puso de manifiesto la situación extrema de sus reiterados clamores de ayuda: “[...] jamás creí que fuésemos tan pedigüeños. Parecemos tres legos de la Seráfica [...] no hubiéramos hecho mal papel al lado de San Francisco, solo falta que el jueves santo nos distribuyamos en tres iglesias y nos pongamos a la puerta con un plato". ACH, Fondo Archivo del General Miguel de La Torre, tomo XVIII, p. 227.

${ }^{1}$ ACH, Fondo Archivo del General Miguel de La Torre, tomo XVIII, p. 229.

${ }^{52}$ ACH, Fondo Archivo del General Miguel de La Torre, tomo XVII, p. 180.
} 
de las huestes realistas ${ }^{53}$. La pérdida definitiva de la capital Caracas luego de la derrota padecida en la batalla de Carabobo del 24 de junio, significó un golpe contundente para las aspiraciones del bando realista y tornó aún más oscuras las perspectivas económicas para las autoridades políticas y militares españolas pues la resistencia se vio reducida a los puertos costeros de Coro, Cumaná y Puerto Cabello luego de haberse reportado la pérdida de la mitad del pie de fuerza disponible.

En realidad, ante estos reveses políticos y militares era muy poca la reacción que se podía esperar de España por cuanto la situación política allí era muy convulsionada $^{54} \mathrm{y}$, ni qué decir de la situación fiscal pues los fondos no alcanzaban ni para los gastos internos y mucho menos para afrontar las voluminosas erogaciones que implicaba una nueva expedición de reconquista militar de los dominios de ultramar ${ }^{55}$.

De cara a estas novedades, el 6 de julio La Torre reiteró el llamado a Cuba en momentos en que apenas se había recibido una primera remesa con 500 quintales de tabaco de mala calidad que rebajaba sustancialmente su precio, el cual fue repartido entre algunos acreedores de la Real Hacienda mientras que el otro cargamento se había perdido en el tránsito. Se pidió entonces la urgente remisión de al menos 5.000 raciones para abastecer la tropa durante seis meses ${ }^{56}$. Como medida extraordinaria y, ante la falta de opciones, se recibió de los comerciantes de Puerto Cabello todos los productos de primera necesidad bajo la modalidad de crédito para lo cual se recomendó el pago de las letras giradas a favor de Mr. Peter Harmony del comercio de Nueva York por valor de 6.069 pesos $^{57}$.

En un tono de desesperación, el 20 de agosto La Torre comentaba al Secretario de Estado y del Despacho Universal de la Guerra el infructuoso balance de la gestión de los comisionados destinados a La Habana y urgía el pronto envío de auxilios. Los artículos remitidos por lo general llegaban a un alto precio y fue así como pese a que Gárate había clamado por un auxilio monetario de 24.575 pesos, estos se habían librado en 2.000 barriles de harina y 500 piezas de brea. Argumentó La Torre que con este metálico podía resultar más fácil adquirir en las colonias extranjeras vecinas víveres básicos a precios más equitativos para el sostenimiento de la tropa. El problema era mayor al saberse de manera extraordinaria que los bergantines El Príncipe Eugenio y El Dans en que venían esos cargamentos cambiaron súbitamente de rumbo el $1^{\circ}$ de julio sin que se supiera el paradero aunque en Curazao se rumoraba que los capitanes de las naves habían decidido entregar el cargamento a los "insurgentes" de Santa Marta.

\footnotetext{
${ }^{53}$ Según los estimativos, por estos días el ejército español contaba apenas con 5.700 hombres, aquejados por la miseria y con escasos apoyos por parte de los gobiernos locales y provinciales. Feliciano Montenegro, Verdaderos acontecimientos de Venezuela a principios del año 1821, Puerto Rico, Impreso por D. Julián Blanco, 1823, p. 2.

${ }^{54}$ Archivo Santander, Bogotá, Águila Negra Editorial, 1916, Vol. VI, p. 304.

${ }^{55}$ Pedro A. Zubieta, Apuntes de las primeras misiones diplomáticas de Colombia, Bogotá, Imprenta Nacional, 1924, p. 353.

${ }^{56}$ ACH, Fondo Archivo del General Miguel de La Torre, tomo XVII, pp. 188, 200; tomo XIX, p. 305

${ }^{57}$ ACH, Fondo Archivo del General Miguel de La Torre, tomo XXVI, p. 162.
} 
La Torre se sentía frustrado al ver cómo, después de cinco meses de gestión por parte de los comisionados, los socorros gestionados no cumplían el propósito deseado al tiempo que proliferaban las complicaciones. Por todo ello, dio un ultimátum a sus mandos superiores en España en el sentido de que si sus últimas peticiones a La Habana y el envío de comisionados a Puerto Rico y colonias extranjeras no arrojaban resultados satisfactorios, evacuaría la plaza pues no quería ver perecer los restos de su "heroico" ejército sin que se le atribuyese responsabilidad pues varias veces había alertado sobre esta situación $^{58}$. En el informe rendido a finales de septiembre por su enviado especial Joseph Domingo Juez ante el gobierno central en Madrid, se expresó también el sentimiento de desilusión al ver cómo desde La Habana solo de vez en cuando se recibían pequeñas ayudas ${ }^{59}$.

El panorama para la plaza de Cartagena no era mejor por cuanto nada había recibido el gobernador Gabriel de Torres después de su pedido elevado el 11 de abril al tiempo que el general La Torre le había anunciado su imposibilidad de enviar refuerzos de pie de fuerza debido a los escollos acaecidos en Venezuela después de la pérdida sufrida en la batalla de Carabobo. Así entonces, se recomendó al gobernador que entrara en contacto directo con el capitán general nombrado para la Nueva Granada Juan de la Cruz Murgeon o con el gobernador de La Habana con miras a ver si lograba un pronto paliativo a sus penurias ${ }^{60}$.

A principios de octubre, La Torre hizo extensivo su llamado de ayuda al capitán general de Puerto Rico don Gonzalo Aróstegui ante el hecho de que solo contaba con víveres en los almacenes para doce días de subsistencia mientras que las cajas yacían exhaustas. Al recibir esta petición, Aróstegui citó a junta de comerciantes y hacendados para explorar alternativas de ayuda ante los esquilmados recursos oficiales y el reciente recaudo de 40.000 pesos para alimentar a los emigrados de Venezuela y la multitud de oficiales inútiles del ejército que pasaban luego a la península. Por lo pronto, consiguió que el bergantín Palomo de propiedad del coronel don Francisco Illas suspendiera la venta de harinas en la isla y se dirigiera urgentemente a Puerto Cabello con miras a calmar allí las necesidades de subsistencia más acuciantes. En la junta de comerciantes pudo palparse la casi nula disponibilidad de apoyo. Así, por ejemplo, Mr. Simens no ofreció nada a menos que se le asegurara el pago en Puerto Rico en tanto que Mr. Lor adujo no poder colaborar por falta de víveres pues estaba a la espera de la llegada de un bergantín. Algunos más se excusaron por tener prestados a la Contaduría parte de sus fondos y otros simplemente se quejaron por estar ilíquidos en ese momento ${ }^{61}$.

El 9 de octubre desde La Habana contestó el superintendente don Julián Fernández Roldán al intendente del Ejército de Venezuela lamentándose por

\footnotetext{
${ }^{58}$ ACH, Fondo Archivo del General Miguel de La Torre, tomo XXVI, pp. 89-90.

${ }^{59} \mathrm{ACH}$, Fondo Archivo del General Miguel de La Torre, tomo XXXIV, p. 83.

${ }^{60} \mathrm{ACH}$, Fondo Archivo del General Miguel de La Torre, tomo XXIX, pp. 178-179.

${ }^{61} \mathrm{ACH}$, Fondo Archivo del General Miguel de La Torre, tomo XXVI, p. 114; tomo XXVII, pp. 47, 52.
} 
no poder responder a los mandatos de ayuda proferidos por el Rey pues debía afrontar de manera prioritaria el gravoso sostenimiento de la guarnición con su numeroso Estado Mayor, el apostadero de Marina, los gastos de fortificación, el hospital militar, el pago de sueldos, el socorro de los empleados emigrados y los militares que huyendo de la ofensiva republicana llegaban a la isla para seguir a otros destinos y otras tantas obligaciones de imprescindible atención para las cuales no bastaban los menguados ingresos de la Aduana que era la única "mina" y principal fuente de ingresos para la isla cuya prosperidad iba en notable decadencia, todo esto agravado con el estado de inquietud en los pobladores ante las desafortunadas noticias recibidas de Nueva España y de otros dominios hispánicos. A este desolador panorama se sumaba el hecho de que sus predecesores habían dejado exhaustas las cajas y con otros grandes empeños que debían atenderse como el que se derivó del envío de socorros a Puerto Cabello en el mes de junio bajo la escolta del bergantín Hércules. Inútiles habían resultado sus llamados a la Junta Superior Gubernativa de Hacienda de la isla, instancia que, ante los apuros económicos expuestos, recomendó que por falta de capacidad había que suspender la ayuda requerida por las provincias de Costa Firme y el pago de las libranzas pues ahora lo que estaba en primera línea de atención era la seguridad y supervivencia política y económica de la isla ${ }^{62}$.

En un intento por obtener una respuesta favorable, Gárate entabló contacto directo con la Junta de Hacienda que, en su dictamen del 19 de octubre, anunció que no había forma alguna de brindar auxilio pues los pocos recursos disponibles eran imprescindibles para los gastos internos, ni tampoco había cómo atender los 480.389 pesos de las libranzas giradas por las autoridades de Costa Firme a cargo de las cajas de La Habana. Otra prueba de la apretada situación económica era el hecho de que el Consulado no había podido completar el empréstito de 70.000 pesos solicitados para financiar la expedición militar a la ciudad costera de Veracruz, en territorio de Nueva España. Ante esta respuesta, el comisionado, cansado ya de tantas indiferencias y dilaciones, dio por concluida su misión y partió de la isla el 5 de diciembre no sin antes reiterar a los funcionarios de Hacienda el grado de responsabilidad que les asistía y el desprecio que habían mostrado hacia los mandatos del Rey en momentos tan cruciales en los que se temía la pérdida total del territorio de Venezuela ${ }^{63}$.

Por estos días se reiteró desde Venezuela el pedido al virrey de Nueva España para que cumpliera con los auxilios dictaminados por el Rey y en especial por el pago de los 37.000 pesos que uno de los acaudalados comerciantes de Puerto Cabello había entregado en víveres para el sostenimiento de la plaza ${ }^{64}$. Sin embargo, ninguna ayuda logró el comisionado José Olazarra, quien debió regresar ante la imposibilidad de llegar a la capital, ciudad de México, y tras haberse visto en el extremo de vender parte de su equipaje para sobrevivir en

\footnotetext{
${ }^{62}$ ACH, Fondo Archivo del General Miguel de La Torre, tomo XVII, pp. 206-208.

${ }^{63} \mathrm{ACH}$, Fondo Archivo del General Miguel de La Torre, tomo XXXIV, pp. 135-154

${ }^{64} \mathrm{ACH}$, Fondo Archivo del General Miguel de La Torre, tomo XVII, p. 214.
} 
Veracruz al no recibir ningún estipendio del gobierno local para su sostenimiento. Las repercusiones de esta escasa ayuda externa reflejada en el estado de insolvencia y precariedad padecido por el ejército español de Costa Firme seguían causando más estragos por cuanto por esos días los comandantes militares realistas se habían visto tan agobiados y acorralados que no tuvieron más opción que firmar capitulaciones en las plazas de Cumaná ${ }^{65}$ y Cartagena ${ }^{66}$.

Nuevas noticias llegaron a principios de diciembre a Costa Firme procedentes de La Habana por cuenta del teniente coronel Antonio Tobar, quien hasta hacía pocos meses había ocupado la gobernación de Cumaná y ahora aprovechaba su estadía en la isla para sumarse a la intensa labor de gestionar recursos. Al escuchar de su voz el balance de la situación en Venezuela, Mahy reconoció tan lamentable suerte y prometió hacer cuanto le fuera posible. No halló Tobar el mismo ánimo de colaboración en los ministros de la isla debido a que por esos días llegaban varios grupos de emigrados de Nueva España tras la pérdida de este territorio, así como también de las tropas capituladas de Cartagena aunque se abrió una luz de esperanza con los réditos derivados del secuestro de los monacales. La crisis económica interna había obligado a entregar a todos los militares de la isla solo la media paga a partir del mes de enero ${ }^{67}$.

Un fatal golpe al exánime ejército expedicionario confinado en Puerto Cabello y a los pocos que contribuían con su sostenimiento fue la orden dictada el $1^{\circ}$ de octubre por el ministro de Hacienda de España que prohibió a las autoridades de ultramar girar libranzas contra la Tesorería de la Nación por carecer de los fondos para satisfacer estas obligaciones. Esto motivó a la Junta de Pacificación de Caracas a clamar a las Cortes reconsiderar esa medida al ver con sorpresa cómo se trataba con incuria los trastornos vividos en Costa Firme ${ }^{68}$.

Al ver que nada había logrado con sus múltiples reclamaciones, el 9 de junio de 1822 La Torre volvió a reiterarle al capitán general de La Habana un angustioso llamado al reportar que el pasado 13 de abril varios buques republicanos habían rodeado Puerto Cabello y por tierra el general José Antonio Páez se había presentado con su bien equipado ejército formalizando de esta forma el sitio. La Torre estaba convencido de que se vería en el extremo de evacuar la plaza si no se recibía prontamente las ayudas. Se aspiraba a que el gobierno de la isla mostrara un verdadero compromiso de solidaridad que fuera más allá del pago que adeudaban las casas de comercio de aquella plaza a las cajas nacionales ${ }^{69}$.

\footnotetext{
${ }^{65}$ La pérdida de esta plaza se debió al hecho de no haber dinero para socorrer los buques que debían escoltar allí los víveres que hacía cuarenta días estaban detenidos en Puerto Cabello.

${ }^{66}$ ACH, Fondo Archivo del General Miguel de La Torre, tomo XXVI, p. 153; tomo XXXI, p. 297.

${ }^{67}$ ACH, Fondo Archivo del General Miguel de La Torre, tomo XXVIII, pp. 418-419.

${ }^{68} \mathrm{ACH}$, Fondo Archivo del General Miguel de La Torre, tomo XXXIV, p. 225.

${ }^{69} \mathrm{ACH}$, Fondo Archivo del General Miguel de La Torre, tomo XXXIII, p. 187.
} 
Por estos días, este alto oficial dejó su cargo como comandante en jefe de Costa Firme para asumir nuevas responsabilidades en Puerto Rico. Fue reemplazado por su segundo al mando, el general canario Francisco Tomás Morales, quien llegó el 28 de agosto a La Habana en desarrollo de una corta visita y al cabo de tres días presentó un informe al capitán general de la isla sobre las afugias sufridas por los reductos militares españoles en la costa venezolana ${ }^{70}$. Semanas después y, con los escasos recursos que pudo recoger, Morales recuperó militarmente la ciudad de Maracaibo ${ }^{71}$ pero, aun así, las circunstancias no parecían mejorar en los meses siguientes. El 22 de octubre un grupo de 22 oficiales del Ejército Expedicionario confinados en Puerto Cabello enviaron un enérgico mensaje a las Cortes poniendo de presente la crítica situación económica y exigiendo medidas perentorias pues de lo contrario sobrevendría la pérdida definitiva de estos territorios ${ }^{72}$.

Finalmente, la ayuda nunca llegó y en 1823 las débiles fuerzas expedicionarias debieron firmar la rendición de sus dos últimos bastiones: Maracaibo y Puerto Cabello.

Aún en las décadas posteriores a la liberación de Costa Firme, en Puerto Rico siguieron escuchándose varias reclamaciones de viudas exiliadas empobrecidas que imploraban ayuda económica como compensación por los créditos otorgados por sus esposos acaudalados al gobierno monárquico en Venezuela durante los años álgidos de la guerra ${ }^{73}$.

\section{Los dilemas del recibo de los capitulados de Costa Firme}

Desde los años de la revolución haitiana a finales del siglo XVIII, el Caribe español había recibido sucesivas oleadas migratorias. Ese flujo de inmigrantes se acentuó poco tiempo después con motivo de las guerras de Independencia hispanoamericana ${ }^{74}$. A raíz de la llegada de estos grupos de emigrados, las autoridades españolas peninsulares concentraron sus energías en fortalecer sus mecanismos de defensa para evitar que se repitieran esos brotes revolucionarios que ya habían logrado menguar el poderío hispánico en el Nuevo Mundo ${ }^{75}$.

\footnotetext{
${ }^{70}$ Enrique Ortega Ricaurte, Bloqueo, rendición y ocupación de Maracaibo por la Armada Colombiana al mando del Almirante D. José Padilla, Bogotá, Sección de Imprenta y Publicaciones de la Armada Nacional de Colombia, 1947, pp. 126-134.

${ }^{71}$ Delfina Fernández, Últimos reductos españoles en América, Madrid, Editorial Mapfre, 1992, p. 117.

${ }^{72}$ ACH, Archivo del General Miguel de La Torre, tomo XVI, pp. 58-69.

${ }^{73}$ Alejandro Cardozo Uzcátegui, "El Ramo del Cacao. Exilio, pobreza y lealtad de los inmigrantes venezolanos en Puerto Rico, 1813-1873". Revista de Indias, LXXXI, 282, (2021): 489-490.

${ }^{74}$ Sobre el fenómeno inmigratorio véase: Estela Cifre, La inmigración a Puerto Rico durante el siglo XIX, San Juan, ICP, 1964; Consuelo Naranjo y Armando García, Racismo e inmigración en Cuba en el siglo XIX. Aranjuez, Ediciones Doce Calles, 1996. El conflicto político y militar por la emancipación política fue especialmente intenso en Venezuela en donde afectó todos los sectores de la sociedad, sin distingos de clase o condición social. Durante los más de diez años de lucha por el poder, había existido una estela de odios y venganzas cuya máxima expresión se dio durante la denominada Guerra a Muerte decretada en 1813. Recurrentes fueron los destierros y las amenazas que obligaban a varios habitantes a emigrar hacia otras tierras en busca de salvaguardar sus vidas, aunque algunos indultos promulgados por uno y otro bando lograron atemperar el ánimo guerrerista prevaleciente. Sobre este asunto, véase: Véronique Hébrard, Venezuela independiente. Una nación a través del discurso (1808-1830), Frankfurt/Madrid, Vervuert/Iberoamericana, 2012.

${ }^{75}$ Rafael L. Cabrera Collazo, "Inmigración peninsular y economías de subsistencia en Puerto Rico en la transición hacia el siglo XX”, en Jesús Navarro García, José Hernández Palomo y Ángel Luis Vélez (coords.), El Caribe y sus relaciones con España: políticas y sociedades en transformación (siglos XIX-XX). San Juan: Universidad Interamericana de Puerto Rico, 2013, p. 141 .
} 
Particularmente, entre los años de 1819 y 1823 , es decir en la fase postrera de la guerra, se tornó más crítico el arribo de vecinos, funcionarios y militares evacuados de los territorios de Costa Firme a raíz de las sucesivas capitulaciones de los últimos bastiones del dominio monárquico ${ }^{76}$ : La Guaira, Cumaná, Santa Marta, Cartagena, Maracaibo y Puerto Cabello. Así entonces, uno de los puntos claves incluidos en esos pactos de rendición fue precisamente la salida de estas gentes. En vista de las dificultades logísticas y económicas que acarreaba el traslado hacia España que era el anhelo de muchos, en especial de los peninsulares, la más sensata y lógica opción era enviarlos hacia otros dominios hispanoamericanos, principalmente La Habana y Puerto Rico ${ }^{77}$ que eran los más cercanos.

No obstante, albergar tan desbordada cantidad de personas como producto de estos convenios se convirtió en un motivo constante de preocupación para los gobernantes de aquellas islas receptoras, pues los recursos eran limitados y apenas alcanzaban para satisfacer las necesidades básicas internas. En algunos casos, debían además asumirse otras erogaciones como el traslado de los capitulados y la atención sanitaria de los militares que venían heridos y enfermos. Estos problemas resultaron agravados a raíz de las diferencias de criterio para atender este cúmulo de necesidades e incluso alcanzó a generar algún nivel de fricción entre los angustiados jefes políticos y militares de Costa Firme y los de aquellas islas caribeñas en momentos en que se veía cada vez más lejana la posibilidad de ayuda por parte del gobierno de España.

La primera salida masiva de militares, funcionarios y vecinos afectos a la causa del Rey se dio con ocasión de la pérdida de la capital Caracas a finales de junio de 1821 y la posterior capitulación de la plaza de La Guaira a comienzos del siguiente mes. Fue así como por estos días se reportó la salida desde La Guaira y Puerto Cabello de más de 60 embarcaciones que con la ayuda del capitán de fragata Ángel Laborde y del comandante de marina León Iturbe fueron habilitadas para llevar hasta la isla de Puerto Rico al menos 3.000 personas $^{78}$.

El caso de los rendidos de Cumaná es muy revelador respecto a la compleja coyuntura de la precipitada salida de cientos de personas hacia el Caribe insular. En las capitulaciones firmadas el 15 de octubre de 1821 se acordó que la guarnición sería considerada como prisionera de guerra y saldría con los honores correspondientes hacia Puerto Rico ${ }^{79}$. Fueron en total 700 hombres los que se embarcaron el 24 de octubre.

\footnotetext{
${ }^{76}$ Sobre más detalles de las capitulaciones como opciones negociadas al conflicto, véase: Francisco Alfaro Pareja, $L a$ Independencia de Venezuela relatada en clave de paz. Las regulaciones pacíficas entre patriotas y realistas (1810-1846), Castellón, Universitat Jaume-I, 2013, pp. 345-371.

${ }^{77}$ Sobre las oleadas migratorias a esta isla véase: Raquel Rosario-Rivera, Los emigrantes llegados a Puerto Rico procedentes de Venezuela entre 1810-1848, Hato Rey, Inter American University, 1993.

${ }^{78} \mathrm{ACH}$, Fondo Archivo del General Miguel de La Torre, tomo XXXIV, pp. 80, 95.

${ }^{79}$ Para el caso de Puerto Rico, desde las primeras oleadas migratorias se experimentaba una crisis económica marcada por altos niveles inflacionarios. A. Cardozo Uzcátegui, "El Ramo del Cacao”, pp. 480-481.
} 
Mediante oficio fechado el $1^{\circ}$ de noviembre, el comandante Juan Garcén de San Just informó haber arribado en la tarde del 28 de octubre al puerto de Ponce seis buques conduciendo parte de las tropas de la guarnición cumanesa $^{80}$. Así entonces, habían entrado algunos del segundo batallón de Granada y de las compañías del batallón de Navarra y se esperaba de un día a otro el arribo del resto. Primero que todo, el capitán general Gonzalo Aróstegui dispuso que la tropa se agregara al primer batallón de Granada y que los jefes y oficiales siguieran a La Habana tan pronto como fuera posible pues en Puerto Rico no había cómo mantenerlos ante lo cual se estaba a la espera de la resolución de La Torre sobre esta situación ${ }^{81}$.

Rafael Sevilla era uno de los capitanes españoles capitulados y esto fue lo que recordó de esos momentos en los que ingresó a la isla: “¡Al fin pisábamos tierra hermana y hospitalaria! Al fin teníamos un hogar donde reclinar la cabeza, descansar de tantas amarguras y recordar tantas proezas y epopeyas tantas de sublime valor y fortaleza de ánimo" 82 . Sin embargo, la realidad muy pronto lo convenció de que la nueva vida en la isla no sería tan halagüeña como se esperaba.

El comandante del $2^{\circ}$ batallón de Granada don Pío Sánchez Garcés, quien venía al mando de ese primer contingente, a su entrada a la isla entregó un paquete de documentos al capitán general Aróstegui enviados por el rendido gobernador José Caturla entre los que figuraban los términos de las capitulaciones suscritas. Tan pronto llegaron estas tropas, ante el estado de penuria de las arcas oficiales, Aróstegui adoptó medidas excepcionales junto con la Diputación Provincial para suministrarles los alimentos básicos. La mayor parte estaba en la ciudad de San Juan y a los jefes y oficiales se les socorría con cuatro reales diarios y a la tropa con los ocho novenos de su haber. Pero, ante el hecho de que terminaran esquilmadas las arcas locales, se dispuso ubicar la tropa al servicio de la guarnición para lo cual se ordenó el retiro temporal de la milicia disciplinada que estaba operando al interior de la plaza. Ante la imposibilidad de seguir la isla asumiendo tan cuantiosa carga económica por largo tiempo, se reiteró a La Torre que dispusiera lo antes posible el destino de esta tropa dependiente de su ejército ${ }^{83}$.

El 6 de diciembre arribó a la isla el coronel José Caturla con el resto de las tropas de su guarnición compuesta de 60 oficiales, un físico y 599 plazas de fusil. Uno de aquellos militares, el oficial español Antonio López de Mendoza, relató cómo el viaje había durado ocho días y seis horas, quejándose del excesivo número de personas embarcadas que hizo más penoso el desplazamiento ${ }^{84}$. Al pisar el suelo de la isla, esta fue su primera y

\footnotetext{
${ }^{80} \mathrm{El}$ total de desembarcados fueron 657: 3 jefes, 18 capitanes, 19 tenientes, 27 subtenientes, 67 sargentos, 33 tambores, 86 cabos y 404 soldados. Francisco Javier Yanes, Historia de la provincia de Cumaná 1810-1821, Caracas, Ministerio de Educación, 1949, pp. 300-309.

${ }^{81}$ ACH, Fondo Archivo del General Miguel de La Torre, tomo XXVII, p. 50.

${ }^{82} \mathrm{ACH}$, Fondo Archivo del General Miguel de La Torre, tomo XXVII, p. 285

${ }^{83} \mathrm{ACH}$, Fondo Archivo del General Miguel de La Torre, tomo XXVII, p. 53.

${ }^{84}$ ACH, Fondo Archivo del General Miguel de La Torre, tomo XXVII, p. 250.
} 
poco alentadora impresión: "Aquí estamos en la mayor miseria y todos deseando marcharnos a La Habana a ver si hay alojamientos y dinero para vivir o bien a cualquier otra parte" 85 .

Al percatarse de la magnitud de esta segunda oleada de capitulados, Aróstegui advirtió con no poca preocupación cómo las cajas de la isla apenas alcanzarían para alimentar la guarnición hasta el mes de diciembre. El panorama económico a nivel interno se había visto agobiado por el reciente recaudo de un abultado donativo de más de 50.000 pesos enviados por orden del gobierno de España para auxiliar a Venezuela después de la pérdida de la batalla de Carabobo, siendo además crítica la situación de los empleados locales.

En carta remitida el 23 de enero de 1822, por tercera vez Aróstegui urgió de manera expresa a La Torre para que diese destino a la tropa estacionada temporalmente en la isla pues no había cómo sostenerla. Lo instó además a cortar el flujo de oficiales y jefes que llegaban diariamente desde distintos parajes de Venezuela, unos con licencia temporal, otros enfermos y otros con destino a la península a donde no había más opción que embarcarlos en el bergantín correo de España que pasaba mensualmente pero sobre esto existía el inconveniente de que sus comandantes siempre se resistían a admitir a bordo militares por venir ocupada toda la cámara de la embarcación ${ }^{86}$.

Reiteró Aróstegui las críticas circunstancias por las que atravesaba la isla a causa de la escasez de dinero y la falta de buques, todo lo cual hacía inviable responder en ese momento a la solicitud de garantizar el regreso de los restos de la guarnición de Cumaná a la plaza de Puerto Cabello ${ }^{87}$. Con desconsuelo, el coronel Caturla reportó desde la isla que en los barcos que venían de España se rumoraba de manera generalizada que no vendrían más auxilios a América en momentos en que todavía estaba viva la tensión política en la península ${ }^{88}$.

Sobre estas inquietudes, La Torre contestó aduciendo que, de acuerdo a lo concertado en las capitulaciones de Cumaná, los oficiales y demás gente de tropa se hallaban ya habilitados para operar ofensivamente contra los republicanos, por lo cual le solicitó en aras de aplacar la carga de las arcas oficiales de la isla, resolver el proceso de retorno de aquellas tropas a Puerto Cabello o a Coro para que sirvieran de refuerzo a los cuerpos de resistencia que allí se estaban formando pero, si el $2^{\circ}$ batallón de Granada manifestaba alguna repugnancia en volver ${ }^{89}$, podía quedarse. En cuanto a los oficiales que obtenían licencias temporales o eran transeúntes en aquella isla, La Torre alegó no estar en capacidad de recibirlos debido a la asfixiante situación padecida en Venezuela, muy diferente a la de la isla en donde, según él, se disfrutaba de un relativo estado de calma con una estable actividad comercial

\footnotetext{
${ }^{85} \mathrm{ACH}$, Fondo Archivo del General Miguel de La Torre, tomo XVII, p. 130.

${ }^{86} \mathrm{ACH}$, Fondo Archivo del General Miguel de La Torre, tomo XXVII, pp. 12, 55-56.

${ }^{87} \mathrm{ACH}$, Fondo Archivo del General Miguel de La Torre, tomo XXXI, p. 152.

${ }^{88} \mathrm{ACH}$, Fondo Archivo del General Miguel de La Torre, tomo XXXI, p. 132, 152

${ }^{89} \mathrm{ACH}$, Fondo Archivo del General Miguel de La Torre, tomo XXXV, p. 114.
} 
que proporcionaba medios para la subsistencia. Reconoció el general en jefe estar inmerso en una encrucijada bastante compleja tras el sitio de Puerto Cabello en donde cada día se hacía más embarazosa la manutención de la tropa y en momentos en que no contaba con ningún apoyo externo. Con la siguiente reflexión intentó persuadir una vez más al gobernador sobre los motivos por los que creía justo y necesario que aquella isla aliada hiciera un sacrificio por aquellos militares: "[...] ¿y será razonable que el oficial que después de tantos padecimientos en una guerra desconocida de todo al que está fuera de este país, viéndose enfermo sin esperanzas de restablecimiento si no pasa a otra provincia, le haga perecer por término de sus fatigas por no gravar alguna cosa a esos infelices habitantes?"90.

Teniendo bloqueada la comunicación directa con la península, creía La Torre injusto que no se les permitiera a los inutilizados llegar hasta allí a través de la isla como punto de escala, en momentos en que no había en Venezuela posibilidades de excusarse de aliviar tantas "bocas que perjudican la defensa y el erario". Insistió en que estaba haciendo denodados esfuerzos por atender tal cúmulo de necesidades en medio de ese ambiente tan hostil y prometió que muy pronto se movilizaría hasta Puerto Cabello en donde examinaría el estado de los buques de guerra apostados en esta plaza para enviarlos a la isla y traer en ellos de regreso a los oficiales que ya estuviesen restablecidos o hubiesen cumplido sus licencias pero, mientras tanto, pidió tener paciencia y clamó a la máxima autoridad de Puerto Rico para que no escatimara energías en seguir socorriendo a aquellos militares.

Tan pronto don José de Navarro asumió interinamente el 16 de febrero de 1822 la capitanía general de la isla, reiteró estar a la espera de los buques de guerra que La Torre ofreció enviar para remitir a Puerto Cabello los restos de la guarnición de Cumaná. Confesó haber hecho todo lo que estaba a su alcance para mantener la tropa aunque con más limitaciones de lo que podía franqueárseles en La Habana ${ }^{91}$.

Al mes siguiente, el subinspector de Infantería Juan Francisco Mendivil reiteró desde Puerto Cabello la necesidad de reclamar al gobernador de Puerto Rico 14 oficiales y sargentos que habían pasado a aquella isla tras la rendición de Cumaná. Esto en razón a que por la capitulación de Coro se encontraban estos militares habilitados para empuñar de nuevo sus armas en Venezuela. En momentos en que se acentuaba el sitio en torno a Puerto Cabello, se consideraba valiosa la presencia de estos hombres para reforzar las tropas que hacían resistencia ${ }^{92}$.

Varios fueron los caminos por los que optaron los capitulados. Algunos regresaron a España en tanto que otros fueron reubicados en las fuerzas locales. En el caso del mencionado capitán Rafael Sevilla, contó con la

\footnotetext{
${ }^{90} \mathrm{ACH}$, Fondo Archivo del General Miguel de La Torre, tomo XXVII, p. 13.

${ }^{91} \mathrm{ACH}$, Fondo Archivo del General Miguel de La Torre, tomo XXVII, p. 57.

${ }^{2}$ ACH, Fondo Archivo del General Miguel de La Torre, tomo XX, pp. 208-209.
} 
oportunidad de seguir desarrollando su carrera militar en la isla. En 1824 fue agregado al Estado Mayor General de la plaza, luego de haber pasado la tropa de su batallón al de Granada y se le nombró para instruir el cuerpo de voluntarios de Puerto Rico. Al cabo de dos años, fue $2^{\circ}$ comandante de la milicia provincial y luego nombrado teniente justicia mayor del distrito de Caguas y en 1832 se posesionó como comandante militar de esta provincia. Ascendió a teniente coronel y ocupó otros cargos administrativos al interior del Ejército hasta 1847 cuando regresó a España ${ }^{93}$.

Además de Puerto Rico, fue la isla de Cuba la que debió afrontar el recibo del mayor número de militares capitulados y de emigrados por cuanto allí llegaron los que venían de Santa Marta, Cartagena, Pasto, Quito, Maracaibo y Puerto Cabello. En estos procesos de rendición ya había quedado explícita la expresa condición de que aquellos militares no podían bajo ninguna circunstancia volver a empuñar las armas contras los republicanos en Costa Firme, lo cual implicaba que la isla receptora debía asumir irremediablemente todos los costos de sostenimiento económico de estos hombres.

El 20 de diciembre de 1820 arribó a Cuba procedente de Santa Marta un buque extranjero conduciendo los oficiales, la tropa y los empleados de esta plaza ya sometida al gobierno de los "insurgentes". El realista José Morote explicó cómo las autoridades republicanas prometieron brindar protección a los afectos a la causa realista con la oportunidad de acceder a un pasaporte para trasladarse a ultramar. Fue así como fueron saliendo de los montes y de sus escondites muchos perseguidos, confiados en la buena fe de las fuerzas sitiadoras. No obstante, inexplicablemente luego recogieron algunos de esos permisos a aquellos que habían servido al gobierno español y a aquellos que creían sospechosos, enviándolos a prisión y tratándolos desconsideradamente pero contaron con la ayuda de Mr. Gaspar Leoni, capitán de la goleta angloamericana Alexander Hamilton, quien ofreció llevar a estos prisioneros hasta aquella isla del Caribe. Morote, en representación de otros 50 emigrados, pidió al gobernador de Cuba don Eusebio Escudero apoyo para su subsistencia ${ }^{94}$.

El 19 de octubre de 1821 atracaron en el puerto de La Habana las naves que traían el Regimiento de Infantería de León encargado de guarnecer el capitulado puerto de Cartagena, el último bastión monárquico en costas neogranadinas. Primero arribaron las goletas Bristol, Persile y Hero, y días más tarde se asomaron los cinco buques restantes que integraban el convoy ${ }^{95}$. Según algunos estimativos, 800 militares de la guarnición ${ }^{96}$ y aproximadamente 1.300 vecinos, lo cual equivalía a una décima parte del

\footnotetext{
${ }^{93}$ Rafael Sevilla, Memorias de un oficial del ejército español, Bogotá, Editorial Incunables, edición facsimilar, 1983, $3^{\text {a }}$ edición, pp. 304-307.

${ }^{94}$ José L. Franco (comp.), Documentos para la historia de Venezuela existentes en el Archivo Nacional de Cuba, La Habana, Archivo Nacional de Cuba, 1960, p. 151.

95 Justo Cuño Bonito, El retorno del Rey. El restablecimiento del régimen colonial en Cartagena de Indias (1815-1821), Castello de la Plana, Universitat Jaume, 2008, p. 368.

${ }^{96}$ Manuel Ezequiel Corrales, Documentos para la historia de la provincia de Cartagena de Indias. tomo II, Bogotá, Imprenta de Medardo Rivas, 1883, pp. 476-477.
} 
número total de habitantes de aquella plaza, se embarcaron al lado de la tropa $^{97}$.

En los años posteriores a la liberación de Costa Firme, la Corona alcanzó a establecer a través de la pensión del ramo del cacao ${ }^{98}$ una alternativa dirigida a atender la problemática social derivada de la diáspora de súbditos fieles venezolanos a Puerto Rico, una fórmula de apoyo económico con claras connotaciones políticas pues pretendía recompensar la fidelidad de aquellos exiliados. El beneficio, extendido hasta mediados de siglo, logró beneficiar también a las viudas e hijos de los militares y funcionarios sacrificados y perseguidos por los republicanos ${ }^{99}$.

El intendente de la isla Félix Bourman expresó al rendido gobernador Gabriel de Torres ${ }^{100}$ su compasión con la condición de estos recién arribados, pero puso de presente las afugias internas que afrontaban en ese momento hasta el punto de no tener ni siquiera cómo paliar las necesidades ordinarias pues contaban con pocas existencias de dinero metálico. Por el momento, Bourman no vio otra alternativa que trasladar a las arcas de Hacienda un total de 5.768 pesos existentes en la caja del Consulado para lo cual había que contar con el visto bueno de esta entidad. Quiso el intendente dejar en claro que en ningún momento su intención era ser indolente frente a la sentida demanda de ayuda del coronel al mando del Regimiento. Debía entonces efectuarse con el debido orden el desembarque y demás formalidades de Ordenanza y, de inmediato, Bourman ofició al diputado consular manifestándole la imperiosa necesidad de hacer uso de los fondos de su ramo para el urgente socorro de los recién llegados ${ }^{101}$.

Vale precisar que también era responsabilidad de los gobiernos receptores proporcionar ayuda para el traslado y sostenimiento de los comisionados y garantes de estos procesos de capitulación. El 9 de noviembre el comisionado republicano, capitán J. Manuel Montoya, pidió en La Habana al gobernador militar apoyo para devolverse a Cartagena tras ser llamado urgentemente por su gobierno. Al no haber buques disponibles que viajaran directamente a aquel puerto de Costa Firme, el delegado se vio en la necesidad de hacerlo por la vía de Jamaica para lo cual le pidió al gobernador el dinero requerido para esta travesía en cumplimiento del artículo 13 de la capitulación ${ }^{102}$. Tres meses después, el sargento mayor republicano don Carlos Robledo pidió también auxilio para regresar a la Nueva Granada ${ }^{103}$.

\footnotetext{
${ }^{97}$ Rebecca A. Earle, España y la Independencia de Colombia, 1810-1825, Bogotá: Universidad de Los Andes, 2014, p. 208.

${ }^{98}$ Este apoyo económico era financiado con un impuesto con el que se gravaba el cacao procedente de Venezuela.

${ }^{99}$ A. Cardozo Uzcátegui, "El Ramo del Cacao", pp. 473-501.

${ }^{100}$ A su llegada, este gobernador mandó imprimir un completo informe sobre los detalles del proceso de negociación que condujo a la entrega de la plaza. Véase: Correspondencia oficial que precedió a la rendición de la plaza de Cartagena de Indias entre los jefes español y colombiano, y capitulación de dicha plaza, La Habana, Imprenta del Comercio, de D. Antonio María Valdés, 1821.

101 J. L. Franco (comp.), Documentos para la historia, pp. 161-162. Tomado de: Archivo Nacional Cuba, Correspondencia de los Capitanes Generales legajo 152, Número 3.

102 J. L. Franco (comp.), Documentos para la historia, pp. 163-164. Tomado de: Archivo Nacional Cuba, Correspondencia de los Capitanes Generales legajo 154, Número 2.

${ }^{103}$ J. L. Franco (comp.), Documentos para la historia, p. 165. Tomado de: Archivo Nacional Cuba, Correspondencia de los Capitanes Generales legajo 156, Número 3.
} 
A todas las vicisitudes económicas ya referidas, habría que sumarle también las interferencias registradas al surcar el mar Caribe. El 23 de noviembre el capitán general de Cuba Nicolás Mahy fue informado por el gobernador militar de la preocupación que le asistía ante el hecho de que aún no habían aparecido por el puerto los buques que conducían el resto de la expedición de los capitulados de Cartagena. Por informaciones del gobernador interino de Trinidad se supo que apenas habían llegado a aquel puerto de escala los tres bergantines que transportaban la brigada de Artillería, el resto de las tres compañías del Regimiento y un considerable número de empleados ${ }^{104}$. Luego se recibieron noticias del comandante de armas del surgidero de Batabanó que daban cuenta de que el 15 de noviembre había fondeado en las playas de Batabanó la balandra Desengaño procedente de Trinidad de Cuba que llevaba un cabo y cuatro artilleros de la guarnición de Cartagena, quienes aportaron más detalles sobre los motivos de la demora por haber sido interceptados por un corsario que los despojó de las armas y de todo cuanto tenían en su poder. Estos hombres llegaron finalmente a La Habana el 23 de noviembre y de inmediato fueron auxiliados con cuatro raciones de una tienda de víveres ${ }^{105}$.

A mediados de 1822 el Ejército republicano pudo después de muchos intentos ocupar las ciudades de Pasto y Quito ubicadas al sur de Costa Firme, habiéndose convenido en ambos casos la firma de sendas capitulaciones. De conformidad con lo estipulado en estos acuerdos, en el mes de julio la tropa capitulada y parte del vecindario adepto a la bandera monárquica se embarcaron en Guayaquil en cuatro goletas con rumbo a Cuba. Este contingente, compuesto por 309 hombres, arribó en una primera escala en el istmo de Panamá. Allí el comandante republicano José María Carreño instó a Sebastián de Kindelan, gobernador español de aquella isla, para que asumiera los más de 16.000 pesos correspondientes al costo del traslado de acuerdo a los compromisos contemplados en el tratado de Capitulación. Las afugias económicas obligaron al gobernador español a pedir un plazo de espera para responder a ese compromiso, lo cual generó una nota de protesta del alto mando republicano que exigía el inmediato cumplimiento ${ }^{106}$. Kindelan reportó a mediados de agosto la llegada de los capitulados ${ }^{107}$.

En sesión llevada a cabo el 12 de octubre en Santiago de Cuba, el intendente militar Félix Bourman, los alcaldes y regidores de la ciudad de La Habana y el brigadier Gabriel de Torres quien había sido el último gobernador de Cartagena y ahora fungía como gobernador interino de Cuba, de manera unánime coincidieron en el imperativo de socorrer a estos emigrados ante la incapacidad de la Tesorería Nacional para cubrir tales gastos y ante el hecho

\footnotetext{
104 J. L. Franco (comp.), Documentos para la historia, p. 164. Tomado de: Archivo Nacional Cuba, Correspondencia de los Capitanes Generales legajo 154, Número 3.

105 J. L. Franco (comp.), Documentos para la historia, p. 165. Tomado de: Archivo Nacional Cuba, Correspondencia de los Capitanes Generales legajo 154, Número 3.

106 Documentos que presenta la Intendencia del Istmo, de la conducta de Colombia y España consecuente a las Capitulaciones de Pasto y Quito celebradas entre los Jefes de ambas Naciones, Panamá, Por José María Goytia, 1823, pp. 3-32; Archivo Santander, Vol. IX, pp. 181-182.

${ }^{107}$ J. L. Franco (comp.), Documentos para la historia, p. 176.
} 
de que la guarnición de la plaza apenas percibía lo preciso para que sus hombres "no perezcan de hambre".

Así entonces, se decidió implementar medidas urgentes para atender tales circunstancias extraordinarias y, por ello, esta junta acordó que no había mejor opción que recurrir en ese mismo sábado día de feria a los "patrióticos, humanos y liberales sentimientos de los individuos de este vecindario" para que contribuyeran voluntariamente o con el compromiso del pronto reintegro de sus aportes. Igual convocatoria se había hecho para socorrer a los del Regimiento de Cartagena. El ayuntamiento de la ciudad avaló este procedimiento y de él resultaron a la fecha del 16 de octubre un total de 366 pesos 4 reales, suma que de todos modos resultaba exigua frente a las expectativas que había de recaudar al menos de 3.500 a 4.000 pesos y, por consiguiente, se esperaba que más lugareños se sumaran a este propósito ${ }^{108}$.

La campaña militar de los republicanos siguió mostrando avances sustanciales en los meses siguientes y para 1823 concentraron sus esfuerzos en estrechar el sitio para recuperar a Maracaibo. Tras la victoria obtenida el 24 de julio por este bando en la batalla naval del lago del mismo nombre, se abrió paso a la rendición de las fuerzas realistas, todo lo cual quedó finiquitado a través de la firma de la capitulación el día 3 de agosto ${ }^{109}$, lo cual significaba la desmovilización de buena parte del Ejército Expedicionario español, cuya cifra se elevaba a 2.156 hombres, cuyo destino final era La Habana ${ }^{110}$.

Según los cálculos, el número de civiles emigrados se elevó a $600^{111}$. Dentro de los vecinos cabeza de familia embarcados, se encontró con que 105 eran de origen español, 294 venezolanos, 4 neogranadinos, 3 de Guayana, 2 de Puerto Rico y 2 de la isla de Cuba. Entre los venezolanos, la mayoría eran oriundos de las ciudades de Maracaibo, Coro, Puerto Cabello y Caracas. Algunos salieron con familias numerosas, como fue el caso de doña Juana Lezama con 21 seres queridos y don Juan Bautista Iguarán con 13 integrantes ${ }^{112}$.

Las cifras revelaron que más de un millar de militares lograron desembarcar el 28 de agosto ${ }^{113}$. Este fue el reporte dado al día siguiente desde la bahía de Santiago de Cuba sobre el arribo de estos contingentes:

Ha llegado a esta plaza el Señor Su Excelencia General en Jefe del Ejército Expedicionario de Costa Firme [Francisco Tomás Morales] con 21 jefes,

\footnotetext{
108 J. L. Franco (comp.), Documentos para la historia, pp. 178-180.

109 "Firma de capitulaciones", El Iris de Venezuela, 84, Caracas, Por Valentín Espinal, agosto 22 de 1823, p. 2.

110 José Semprún y Alfonso Bullón de Mendoza, El ejército realista en la Independencia americana, Madrid, Editorial Mapfre, 1992, p. 197.

${ }^{111}$ Francisco Morales Padrón, "Francisco Tomás Morales, último Capitán General de Venezuela". Anuario de Estudios Americanos, XXXIII, (1976): 670.

${ }^{112}$ Archivo General de la Nación de Colombia (AGNC), Sección República, Fondo Secretaría de Guerra y Marina, tomo 41, ff. 361r-366r.

${ }_{113}$ Manuel Muriel Hernández, Manuel Lorenzo: militar y gobernador de Santiago de Cuba, Madrid, Tesis Doctoral de la Universidad Complutense de Madrid, 2012, p. 322.
} 
155 oficiales y 435 hombres de tropa que vienen capitulados de Maracaibo llenos de necesidades consiguientes al sitio que han sufrido. La humanidad y más que todo el deber exigen sacrificios perentorios de parte de estos habitantes para poder auxiliar a estos beneméritos defensores de la Nación ${ }^{114}$.

A bordo de la goleta Especuladora, Morales escribió una nota de saludo al gobernador político de la isla, enterándolo sobre los amargos acontecimientos recientes y adjuntándole una copia del tratado de capitulación, a la vez que acudía a la bondad de los cubanos para acceder a la hospitalidad y los auxilios destinados a quienes se habían hecho acreedores por sus "méritos y sacrificios". Informó además Morales sobre la llegada de los rehenes de ambos bandos para que de las arcas de la isla se le proveyera a cada uno 150 pesos que era el pago pactado en las capitulaciones para el cumplimiento de su misión. Adicionalmente, se procedió a realizar el registro y relación de la artillería, armas y municiones que traía la tropa.

La precariedad de las arcas públicas de la isla impedía soportar la carga que significaba el sostenimiento de estos nuevos contingentes en sus necesidades prioritarias. Ante esto, se hizo indispensable adoptar medidas extraordinarias como la de proponer un "[...] repartimiento vecinal con calidad de donación o reintegro con cuya medida quedará a salvo la tranquilidad pública a la vez que atendidos tan beneméritos individuos"115.

Por lo pronto, el gobernador Torres ofició a los ministros de la Hacienda pública para que desde el día 30 de agosto se les suministraran dos raciones a los oficiales y una a la tropa a razón de dos reales cada una, para lo cual cada cuerpo debía adjuntar la respectiva "papeleta" a los ministros del tesoro público.

En desarrollo de la idea propuesta, la Diputación Provincial en sesión extraordinaria acudió a la "generosidad y filantropía" del vecindario en vista de que escasamente se contaba con el pago de la tropa de la guarnición local, aquejados además por la disminución de la actividad comercial y la merma de las cosechas que eran los ejes de la economía insular. Se acordó entonces un procedimiento para el día 30 de agosto en el cual los regidores, acompañados de los comisarios de policía, debían formar en sus cuarteles la lista de individuos de sus respectivas jurisdicciones debiendo cada uno colaborar según su propio patrimonio. En esta labor debían participar también los capitanes de partido elaborando en el área rural una lista de los naturales y extranjeros así como de los hacendados, cada uno de los cuales sería clasificado como "rico, mediano y pobre" según sus posibilidades materiales.

\footnotetext{
114 J. L. Franco (Comp.), Documentos para la historia, p. 196.

${ }^{115}$ Días antes, el 8 y 9 de julio, llegaron a Santiago de Cuba las goletas mercantes Neptuno y San José, procedentes de Maracaibo, trayendo a bordo oficialidad y tropa, muchos de ellos enfermos y heridos tras los combates que por mar y tierra sostuvieron con la escuadrilla republicana. Estas tropas iban con el ánimo de ser socorridas con el fin de regresar con más refuerzos para respaldar la guarnición que defendía Puerto Cabello. J. L. Franco (comp.), Documentos para la historia, pp. 200-201.
} 
Estos vecinos fueron convocados a un cabildo abierto programado para la noche siguiente ${ }^{116}$.

En momentos en que se estaban requiriendo recursos para socorrer a Puerto Cabello, considerada en ese momento como la "llave de Costa Firme", la Intendencia provincial de Cuba expresó el 24 de septiembre su preocupación ante la incapacidad de seguir subsidiando a la tropa capitulada de Maracaibo. Por estos días, surgió un nuevo gasto cuando el capitulado brigadier Morales comunicó al gobernador militar de la plaza de Santiago de Cuba que era el momento oportuno para que los rehenes republicanos regresaran a Maracaibo pues ya había llegado a la isla la totalidad de las tropas y emigrados.

Según información secreta recibida el 29 de octubre por el general republicano Manuel Manrique, las tropas españolas capituladas tan pronto arribaron a aquella isla habían solicitado licencia absoluta pero estaban a la espera de la contestación definitiva que sobre este particular debía emitir el capitán general de La Habana. Dieron cuenta además de acercamientos secretos entre este mando militar y el general capitulado Francisco Tomás Morales.

A pesar de haberse cumplido los términos de la capitulación, no cesaron los temores y las prevenciones de las autoridades republicanas ante una eventual expedición española proveniente de las islas del Caribe. En agosto de 1823, las autoridades republicanas de Maracaibo recibieron el rumor sobre un supuesto proyecto del capitulado general Francisco Tomás Morales para reunir en La Habana 5.000 negros con el fin de recuperar aquella ciudad venezolana ${ }^{117}$.

Otra prueba de esas amenazas de invasión fueron tres cartas particulares remitidas por emigrados que fueron interceptadas por las fuerzas republicanas. Una de ellas fue redactada el 5 de octubre por el militar realista José Antonio Menéndez a su madre doña Mariana Carrasquero que había quedado viviendo en el barrio el Empedrado de la ciudad de Maracaibo:

Amantísima y querida madre: De toda mi estimación Dios Nuestro Señor y su madre santísima permitan que al recibo de estas letras se hallen gozando de la salud y prosperidad que yo le deseo. Mi madre, le noticio cómo he llegado con toda felicidad desde que me embarqué me puse bueno, solo me ha quedado una tos pero no me fatiga haciéndome remedios estoy para ver si se me quita. / Mi madre, cinco días tengo en este puerto y todavía no he ganado ni aún siquiera un medio, los emigrados que están aquí reniegan porque no hallan a dónde trabajar, esta tierra es bien mala, yo no sé qué será de mí [...] Aquí los emigrados no hallan a dónde vivir [...] Mi madre, démele cinco mil abrazos a mis hijas [...] Los españoles conocidos mandan saludes, a ellos los tienen bien oprimidos [...] Pensando estoy qué

\footnotetext{
${ }^{116}$ J. L. Franco (comp.), Documentos para la historia, p. 205.

${ }_{117}$ AGNC, Sección República, Fondo Secretaría de Guerra y Marina, tomo 41, ff. 428r-462r; Archivo Santander, Vol. XI, p. 38 .
} 
harán los patriotas con usted por mi venida. Mi madre, esto está revuelto, han echado un bando publicando guerra con el francés pero no viva nunca descuidada porque el general [Morales] vuelve a Costa Firme a hacer la guerra y yo vuelvo con él. Mi madre, no canso más, a Dios le pido me la guarde muchos años y me lleve a cuidar de usted en su vejez ${ }^{118}$.

Nótese en este emotivo escrito la incertidumbre de los emigrados a su llegada a aquella isla caribeña, los temores ante las eventuales represalias que podían asestar los republicanos contra su familia en Maracaibo y la alarmante noticia sobre una supuesta expedición para reconquistar Venezuela. Indicios de este último rumor quedaron también consignados en otra correspondencia interceptada, fechada el 7 de octubre y firmada por Francisco Ruiz a un ser querido radicado en la isla de Curazao. Allí se daba cuenta de una proyectada invasión militar que les permitiría a los españoles apoderarse nuevamente de Caracas en el mes de noviembre.

El rumor se acrecentó por estos días al fondear en Maracaibo una goleta procedente de la isla de Santo Tomás, cuyo capitán dio aviso de haber conocido apartes de una carta de un comerciante de Puerto Rico calendada el 19 de octubre en la que se aseguraba que efectivamente se estaba fraguando una expedición de 2.500 hombres y 10 buques de guerra dirigida a atacar Costa Firme. De inmediato, esta información fue puesta a consideración del Secretario de Guerra para que se implementaran las prevenciones del caso ${ }^{119}$. En realidad, estas informaciones sobre una eventual contraofensiva de las fuerzas realistas no eran más que especulaciones por cuanto nunca hubo la voluntad política ni se contaba tampoco con la capacidad económica y militar para emprender tal empresa.

Al arreciar los republicanos su arremetida final, el 10 de noviembre quedó formalizada la rendición ${ }^{120}$ del último bastión monárquico de Costa Firme: Puerto Cabello ${ }^{121}$. Esta plaza, principal fortín militar sobre la costa venezolana, se había constituido en la última receptora del número acumulado de militares derrotados y capitulados, así como también de vecinos emigrados. Al cabo de cinco días, se embarcó la guarnición y a la jornada siguiente zarpó el convoy compuesto por dos corbetas, un bergantín y una goleta que llevaron a estos hombres hasta la isla de Cuba. Desde luego, estas nuevas oleadas de capitulados y emigrados complicaron aún más las posibilidades de apoyo brindadas por la isla.

\section{Consideraciones finales}

De gran importancia fue el apoyo que los dominios novohispanos del Caribe brindaron de acuerdo a sus capacidades a las autoridades y tropas realistas

\footnotetext{
${ }^{118}$ AGNC, Sección República, Fondo Secretaría de Guerra y Marina, tomo 41, ff. 428r-429r.

${ }^{119}$ AGNC, Sección República, Fondo Secretaría de Guerra y Marina, tomo 41, f. 462r.

120 José Antonio Páez, Autobiografía, Medellín, Editorial Bedout, 1973, tomo I, pp. 237-242.

121 Roger Pita Pico, "Puerto Cabello: la rendición del último bastión monárquico en Venezuela durante las guerras de Independencia”. Revista de Historia de América, 158, (2020): 73-103.
} 
que defendieron hasta el último aliento los territorios de Costa Firme en la fase postrera del proceso de Independencia, una constatación más de la solidaridad y de los antiguos vínculos sociales, políticos y económicos que como parte de un mismo imperio se remontaban a más de tres centurias.

El total de vecinos, funcionarios y militares de las últimas plazas capituladas de Venezuela y Nueva Granada que llegaron a República Dominicana, Puerto Rico y La Habana se puede estimar en más de 6.000 individuos. El reducido territorio de estas islas ofrecía en realidad muy poco espacio y los insumos y víveres también eran limitados como para alojar y ubicar tal cantidad de emigrados y capitulados. De todos modos, las autoridades políticas y militares insulares en aras de la solidaridad hicieron todo lo que estuvo a su alcance para afrontar esta situación y, ante la falta de recursos oficiales, recurrieron al apoyo solidario de los particulares, en especial de los hacendados y comerciantes e incluso de los vecinos, tal como ocurrió en Cuba para ayudar a los capitulados de Maracaibo. Desde luego, fue evidente el deterioro de las condiciones sociales y económicas de las islas después de asumir el costo de acoger tal cantidad de personas venidas de Costa Firme ${ }^{122}$. Es importante precisar que, después de la caída de los últimos bastiones monárquicos en Nueva Granada y Venezuela, el exilio hacia las islas caribeñas continuó aunque de manera gradual ${ }^{123}$.

España, sumida en una convulsión política por cuenta de la irrupción de la corriente liberal y sin posibilidades reales de contar con recursos económicos suficientes, finalmente no pudo brindar el respaldo que se esperaba para evitar que aquellos últimos bastiones del régimen monárquico en Venezuela y Nueva Granada sucumbieran frente al avance republicano, ni tampoco les fue posible auxiliar a las oleadas de militares, funcionarios y vecinos emigrados. Prácticamente la metrópoli dejó esta alta responsabilidad a los gobernantes de aquellas islas en medio de un ambiente signado por la crisis económica, la amenaza y la tensión política interna.

Tras la pérdida de los dominios de Costa Firme, proliferaron las amenazas sobre una eventual reconquista organizada desde los territorios hispánicos insulares del Caribe, así como también sobre una ofensiva expansiva del ejército bolivariano sobre aquellas islas. Sin embargo, todo esto quedó en meros rumores por cuanto ninguna de las dos partes contaba con los suficientes recursos y con la capacidad militar suficiente para emprender con éxito una campaña de esas dimensiones ${ }^{124}$.

A fin de cuentas, lo que pudo observarse en los años posteriores a la liberación definitiva de Nueva Granada y Venezuela es que los republicanos bajo el

\footnotetext{
122 Sobre la situación de estas islas receptoras, véase: Antonio Santamaría García, "Las islas españolas del azúcar (17601898). Grandes debates en perspectiva comparada y caribeña”. América Latina en la Historia Económica, 35, (2011): 148176.

${ }^{123}$ Para ampliar el análisis del impacto de estas oleadas migratorias, véase el trabajo de: Marco Mérida Fuentes, Emigración de Venezuela a Puerto Rico tras la Ruptura Colonial. Valencia: T.B. Print CA, 2006.

${ }^{124}$ Sobre esta temática, véase: Rafat Ahmed Ghotme Ghotme, "La política antillana de la Gran Colombia: interpretación realista". Historia y Espacio, 16-55, (2020): 96-129.
} 
liderazgo del general Simón Bolívar se concentraron en el sur del continente con sus operaciones militares y alianzas que le permitieron conquistar el territorio del Perú en su intento por integrar más provincias a su proyecto de consolidar una nueva nación denominada en ese entonces como República de Colombia $^{125}$.

Entre tanto, a excepción de lo sucedido en Santo Domingo que fue ocupada por Haití, el dominio español sobre las Antillas españolas terminó prolongándose por varias décadas más tras los refuerzos militares venidos de España en 1824, la vigilancia ejercida por las fuerzas navales de la flota española dirigida por el comandante Ángel Laborde y los frustrados proyectos planeados desde Costa Firme y Nueva España para extender a esas islas el movimiento independentista ${ }^{126}$.

\section{Bibliografía}

\section{Fuentes documentales de archivos}

Academia Colombiana de Historia (ACH). Bogotá-Colombia. Fondo Archivo del General Miguel de La Torre, tomos XIII-XXXVI.

Archivo General de la Nación de Colombia (AGNC). Bogotá-Colombia. Sección República, Fondo Secretaría de Guerra y Marina, tomo 41.

\section{Fuentes primarias impresas}

Archivo Santander. Vols. VI, IX, XI. Bogotá: Águila Negra Editorial, 1916.

"Capitulaciones", Gaceta de Caracas, Caracas, Imprenta de J. Gutiérrez, noviembre $1^{\circ}$ de 1821.

Colección de documentos relativos a la vida pública del Libertador. Vol. III. Caracas, Imprenta de Devismes Hermanos, 1820.

Corrales, Manuel Ezequiel, Documentos para la historia de la provincia de Cartagena de Indias. tomo II, Bogotá, Imprenta de Medardo Rivas, 1883.

Correspondencia oficial que precedió a la rendición de la plaza de Cartagena de Indias entre los jefes español y colombiano, y capitulación de dicha plaza. La Habana: Imprenta del Comercio, de D. Antonio María Valdés, 1821.

Documentos que presenta la Intendencia del Istmo, de la conducta de Colombia y España consecuente a las Capitulaciones de Pasto y Quito celebradas entre los Jefes de ambas Naciones. Panamá: Por José María Goytia, 1823.

Exposición del estado actual del Ejército Español leída en las Cortes Ordinarias de 1822 el 4 de marzo, conforme al artículo 77 del Reglamento Interior de las Cortes,

\footnotetext{
${ }^{125}$ Armando Martínez Garnica, Historia de la Primera República de Colombia, 1819-1831. «Decid Colombia sea, y Colombia será». Bogotá, Editorial Universidad del Rosario, 2019, p. 147.

${ }^{126}$ J. Semprún y A. Bullón De Mendoza, El ejército realista, p. 169.
} 
por el Brigadier don Luis Balanzat, secretario de Estado y del Despacho de la Guerra. Madrid: En la Imprenta Nacional, 1822.

"Firma de capitulaciones", El Iris de Venezuela, 84, Caracas, Por Valentín Espinal, agosto 22 de 1823 .

Franco, José L. (Comp.), Documentos para la historia de Venezuela existentes en el Archivo Nacional de Cuba. La Habana: Archivo Nacional de Cuba, 1960.

Lee López, Alberto y Horacio Rodríguez Plata (comp.). Documentos sobre la Campaña Libertadora de 1819, tomo III. Bogotá: Editorial Andes, 1971.

Montenegro, Feliciano, Verdaderos acontecimientos de Venezuela a principios del año 1821, Puerto Rico, Impreso por D. Julián Blanco, 1823.

Páez, José Antonio, Autobiografía. tomo I. Medellín: Editorial Bedout, 1973.

Restrepo, José Manuel, Historia de la Revolución de la República de Colombia en la América Meridional. tomo II. Medellín: Universidad de Antioquia-Universidad Nacional, 2009, $5^{\text {a }}$ edición.

Rodríguez Villa, Antonio, El teniente general don Pablo Morillo. Primer Conde de Cartagena, Marqués de la Fuerte (1778-1837). tomo IV. Madrid: Establecimiento Tipográfico de Fortanet, 1910.

Sevilla, Rafael, Memorias de un oficial del ejército español. Bogotá: Editorial Incunables, edición facsimilar, 1983, $3^{\text {a }}$ edición.

"Tratado de Armisticio", Gaceta de Caracas, 19, Caracas, Imprenta de J. Gutiérrez, 6 de diciembre de 1820.

\section{Fuentes secundarias}

Alfaro Pareja, La Independencia de Venezuela relatada en clave de paz. Las regulaciones pacíficas entre patriotas y realistas (1810-1846). Castellón: Universitat Jaume-I, 2013.

Álvarez, Mercedes, Comercio y comerciantes y sus proyecciones en la Independencia venezolana. La Guayra: Tip. Vargas, 1963.

Arellano Moreno, Antonio, Orígenes de la economía venezolana. Caracas: Universidad Central de Venezuela, 1973.

Bushnell, David, El Régimen de Santander en la Gran Colombia. Bogotá: El Áncora, 1985, $3^{\text {a }}$ edición.

Cabrera Collazo, Rafael L., "Inmigración peninsular y economías de subsistencia en Puerto Rico en la transición hacia el siglo XX", en Jesús Navarro García, José Hernández Palomo y Ángel Luis Vélez (coords.), El Caribe y sus relaciones con España: políticas y sociedades en transformación (siglos XIX-XX). Guayama: Universidad Interamericana de Puerto Rico, 2013, pp. 139-170. 
Cardozo Uzcátegui, Alejandro, "El Ramo del Cacao. Exilio, pobreza y lealtad de los inmigrantes venezolanos en Puerto Rico, 1813-1873". Revista de Indias, LXXXI, 282, (2021): 473-501.

Cartay, Rafael, Historia económica de Venezuela 1830-1900. Valencia: Vadell Hermanos Editores, 1988.

Castillo, Ariel, "José Fernández Madrid: poeta cartagenero de la Independencia”, en Haroldo Calvo y Adolfo Meisel (eds.), Cartagena de Indias en la IndependenciaCartagena: Banco de la República, 2011. https://www.banrep.gov.co/es/node/28918

Cifre, Estela, La inmigración a Puerto Rico durante el siglo XIX. San Juan: ICP, 1964.

Cuño Bonito, Justo, El retorno del Rey. El restablecimiento del régimen colonial en Cartagena de Indias (1815-1821). Castello de la Plana: Universitat Jaume, 2008.

Earle, Rebecca A., España y la Independencia de Colombia, 1810-1825. Bogotá: Universidad de Los Andes, 2014.

Fernández, Delfina, Últimos reductos españoles en América. Madrid: Editorial Mapfre, 1992.

Ghotme Ghotme, Rafat Ahmed, "La «política antillana» de la Gran Colombia: interpretación realista". Historia y Espacio, 16-55, (2020): 96-129.

Giménez Silva, Floralgia, La Independencia de Venezuela ante las cancillerías europeas. Caracas: Academia Nacional de la Historia, 1961.

Hébrard, Véronique, Venezuela independiente. Una nación a través del discurso (18081830). Frankfurt/Madrid: Vervuert/Iberoamericana, 2012.

Le Riverend Brusone, Julio, La Habana, espacio y vida. Madrid: Fundación Mapfre, 1992.

Martínez Garnica, Historia de la Primera República de Colombia, 1819-1831. «Decid Colombia sea, y Colombia será». Bogotá, Editorial Universidad del Rosario, 2019.

Meisel Roca, Adolfo, La crisis fiscal de Cartagena en la era de la Independencia, 18081821. Cartagena: Banco de la República, 2007.

Mérida Fuentes, Marco Tulio, Emigración de Venezuela a Puerto Rico tras la Ruptura Colonial. Valencia: T.B. Print CA, 2006.

Morales Padrón, Francisco, "Francisco Tomás Morales, último Capitán General de Venezuela". Anuario de Estudios Americanos, XXXIII, (1976): 641-712.

Muriel Hernández, Manuel, Manuel Lorenzo: militar y gobernador de Santiago de Cuba. Madrid: Tesis Doctoral de la Universidad Complutense de Madrid, 2012.

Naranjo, Consuelo y García, Armando, Racismo e inmigración en Cuba en el siglo XIX. Aranjuez: Ediciones Doce Calles, 1996. 
Ortega Ricaurte, Enrique, Bloqueo, rendición y ocupación de Maracaibo por la Armada Colombiana al mando del Almirante D. José Padilla. Bogotá: Sección de Imprenta y Publicaciones de la Armada Nacional de Colombia, 1947.

Pita Pico, Roger, "Puerto Cabello: la rendición del último bastión monárquico en Venezuela durante las guerras de Independencia". Revista de Historia de América, 158, (2020): 73-103.

Rosario-Rivera, Raquel, Los emigrantes llegados a Puerto Rico procedentes de Venezuela entre 1810-1848. Hato Rey: Inter American University, 1993.

Santamaría García, Antonio, "Las islas españolas del azúcar (1760-1898). Grandes debates en perspectiva comparada y caribeña". América Latina en la Historia Económica, 35, (2011): 148-176.

Semprún, José y Alfonso Bullón de Mendoza, El ejército realista en la Independencia americana. Madrid: Editorial Mapfre, 1992.

Sourdís, Adelaida, Cartagena de Indias durante la Primera República 1810-1815. Bogotá: Banco de la República, 1988.

Vidal Ortega, Antonino, Cartagena de Indias y la región histórica del Caribe, 15601640. Sevilla: Universidad de Sevilla, 2002.

Viloria de La Hoz, Joaquín, "La Independencia en la provincia de Santa Marta". Revista del Banco de la República, 88-1.050, (2015): 17-67.

Von Grafenstein, Joana, "Corso y piratería en el Golfo-Caribe durante las guerras de independencia hispanoamericanas", en Antoine Follain (dir.), Les Justices locales dans les villes et villages $d u X V^{e}$ au XIX ${ }^{e}$ siécle. Rennes : Presses universitaires de Rennes, 2006, pp. 269-282.

Yanes, Francisco Javier, Historia de la provincia de Cumaná 1810-1821. Caracas: Ministerio de Educación, 1949.

Zubieta, Pedro A., Apuntes de las primeras misiones diplomáticas de Colombia. Bogotá: Imprenta Nacional, 1924. 